\title{
Central Opioid Inhibition of Neuroendocrine Stress Responses in Pregnancy in the Rat Is Induced by the Neurosteroid Allopregnanolone
}

\author{
Paula J. Brunton, ${ }^{1}$ Ailsa J. McKay, ${ }^{1}$ Tomasz Ochędalski, ${ }^{2}$ Agnieszka Piastowska, ${ }^{2}$ Elżbieta Rębas, ${ }^{3}$ \\ Agnieszka Lachowicz, ${ }^{\dagger 2}$ and John A. Russell ${ }^{1}$ \\ ${ }^{1}$ Laboratory of Neuroendocrinology, Centre for Integrative Physiology, University of Edinburgh, Edinburgh EH8 9XD, United Kingdom, and Departments \\ of ${ }^{2}$ Comparative Endocrinology and ${ }^{3}$ Molecular Neurochemistry, Medical University of Łódź, 91-425 Łódź, Poland
}

The hypothalamus-pituitary-adrenal (HPA) axis is the major neuroendocrine stress response system. Corticotropin-releasing hormone $(\mathrm{CRH})$ neurons in the parvocellular paraventricular nucleus $(\mathrm{pPVN})$ play a key role in coordinating responses of this system to stressors. The cytokine interleukin-1 $\beta$ (IL-1 $\beta$ ), mimicking infection, robustly activates these CRH neurons via a noradrenergic input arising from the nucleus tractus solitarii (NTS). In late pregnancy, HPA axis responses to stressors, including IL-1 $\beta$, are attenuated by a central opioid mechanism that auto-inhibits noradrenaline release in the PVN. Here we show that the neuroactive progesterone metabolite allopregnanolone induces these changes in HPA responsiveness to IL-1 $\beta$ in pregnancy. In late pregnancy, inhibition of $5 \alpha$-reductase (an allopregnanolone-synthesizing enzyme) with finasteride restored HPA axis responses (rapidly increased pPVN CRH mRNA expression, $\mathrm{ACTH}$, and corticosterone secretion) to IL-1 $\beta$. Conversely, allopregnanolone reduced HPA responses in virgin rats. In late pregnancy, activity of the allopregnanolone-synthesizing enzymes ( $5 \alpha$-reductase and $3 \alpha$-hydroxysteroid dehydrogenase) was increased in the hypothalamus as was mRNA expression in the NTS and PVN. Naloxone, an opioid antagonist, restores HPA axis responses to IL-1 $\beta$ in pregnancy but had no additional effect after finasteride, indicating a causal connection between allopregnanolone and the endogenous opioid mechanism. Indeed, allopregnanolone induced opioid inhibition over HPA responses to IL- $1 \beta$ in virgin rats. Furthermore, in virgin rats, allopregnanolone treatment increased, whereas in pregnant rats finasteride decreased proenkephalin-A mRNA expression in the NTS. Thus, in pregnancy, allopregnanolone induces opioid inhibition over HPA axis responses to immune challenge. This novel opioid-mediated mechanism of allopregnanolone action may alter regulation of other brain systems in pregnancy.

\section{Introduction}

The brain activates the endocrine response to acute stress through multiple stressor processing pathways that converge onto corticotropin-releasing hormone $(\mathrm{CRH})$ neurons in the parvocellular paraventricular nucleus $(\mathrm{pPVN})$ of the hypothalamus (Buller et al., 2001; Choi et al., 2007). During stress, these neurons release $\mathrm{CRH}$ into the hypothalamo-hypophysial portal system, stimulating ACTH secretion from anterior pituitary cor-

\footnotetext{
Received Feb. 6, 2009; revised April 8, 2009; accepted April 9, 2009.

This work was supported by the Biotechnology and Biological Sciences Research Council, British Council, by Medical University of Łódź Grants 502-19-681 and 502-11-581, and by Ministry of Science and Higher Education Grant N404-1077-33 (Poland). We thank Helen Cameron (University of Edinburgh, Edinburgh, UK) for technical assistance. Undergraduate students Joanne Halfacre, Catherine Harrison, and Stella Howgate assisted in some experiments. Prof. Marcel Karperien and Dr. Jakomijn Hoogendam (University of Leiden, Leiden, The Netherlands) provided the plasmid containing $5 \alpha$-reductase CDNA, and Prof. Trevor Penning (University of Pennsylvania, Philadelphia, PA) provided the plasmid containing $3 \alpha$-hydroxysteroid dehydrogenase cDNA. Prof. Vladimir Patchev (Jenapharm, Jena, Germany) gave technical advice on $3 \alpha$-hydroxysteroid dehydrogenase in situ hybridization. Protein measurements were performed at the Medical University of Łódź. Dr. Martin Simmen and Prof. Gareth Leng (University of Edinburgh) provided expert advice on performing the statistical analyses. This paper is dedicated to the memory of Prof. Agnieszka Lachowicz (1961-2008).

${ }^{\dagger}$ Deceased, May 27, 2008.

Correspondence should be addressed to Paula J. Brunton, Centre for Integrative Physiology, Hugh Robson Building, George Square, University of Edinburgh, Edinburgh EH8 9XD, UK. E-mail: p.j.brunton@ed.ac.uk. D0I:10.1523/JNEUROSCI.0708-09.2009

Copyright $\odot 2009$ Society for Neuroscience $\quad$ 0270-6474/09/296449-12\$15.00/0
}

ticotrophs, which drives glucocorticoid (corticosterone) synthesis and secretion by the adrenal cortex. Administration of the cytokine interleukin- $1 \beta$ (IL-1 $\beta$ ), to mimic infection, robustly stimulates this hierarchical hypothalamus-pituitary-adrenal (HPA) axis (Buller et al., 2001; Brunton et al., 2005). IL-1 $\beta$ activates $\mathrm{pPVN}$ CRH neurons via a direct noradrenergic pathway from the nucleus tractus solitarii (NTS) (Rivier et al., 1989). Circulating IL- $1 \beta$ binds to IL-1 receptors on brain microvessel endothelium, triggering local prostaglandin synthesis (Zhang and Rivest, 1999; Rivest et al., 2000), which excites PVN-projecting noradrenergic A2 neurons (Ericsson et al., 1994).

In late pregnancy, reduced activation of pPVN CRH neurons by stressors leads to attenuated ACTH and corticosterone responses (Brunton et al., 2008). This adaptation may be important in altered metabolic and immune balance in pregnancy and in protecting fetuses from adverse programming (Brunton and Russell, 2008). In late pregnant rats, HPA axis responses to systemic IL- $1 \beta$ are essentially absent, through inhibition by an emergent endogenous opioid mechanism (Brunton et al., 2005). Systemic IL- $1 \beta$ still activates NTS neurons in pregnancy, but opioid acting presynaptically blocks IL- $1 \beta$-induced noradrenaline release in the PVN (Brunton et al., 2005). The source of the opioid peptide and receptor is evidently the NTS neurons that 
project to the PVN: mRNA expression for proenkephalin-A (pENK-A) and the $\mu$-opioid receptor (MOR) is increased in the NTS A2 region in late pregnancy (Brunton et al., 2005).

Here we sought to identify the pregnancy signal that induces opioid inhibition of the HPA axis. The female sex steroids estradiol and progesterone are produced in increasing amounts in pregnancy, but mimicking their pregnancy levels in virgin rats does not attenuate HPA axis stress responses (Douglas et al., 2000). However, allopregnanolone $(3 \alpha, 5 \alpha-$ tetrahydroprogesterone or $5 \alpha$-pregnan- $3 \alpha$-ol-20-one) (AP), the neuroactive steroid metabolite of progesterone, is abundant in the brain in pregnancy and can reduce stress-induced HPA axis activity in male rats (Concas et al., 1998). Allopregnanolone is produced by sequential action of $5 \alpha$-reductase and $3 \alpha$-hydroxysteroid dehydrogenase ( $3 \alpha$-HSD), which are both expressed in the brain (Compagnone and Mellon, 2000). As well as allosterically modulating $\mathrm{GABA}_{\mathrm{A}}$ receptors, to enhance the effectiveness of GABA actions (Herd et al., 2007), allopregnanolone can also modulate neuropeptide gene expression (Bali and Kovács, 2003).

Here, we investigate a role for allopregnanolone in restraining HPA axis responses to IL- $1 \beta$ in late pregnancy by inhibiting allopregnanolone synthesis in late pregnant rats and by measuring HPA responses to IL- $1 \beta$ in nonpregnant rats treated with allopregnanolone. Furthermore, we test whether activity and gene expression of the allopregnanolone synthesizing enzymes are increased centrally in late pregnancy. Moreover, we seek evidence that allopregnanolone is involved in the induction and maintenance of the inhibitory opioid mechanism that emerges in pregnancy.

\section{Materials and Methods}

Animals. Female Sprague Dawley rats (initial body weight, 240-290 g; Charles River Laboratories) were housed under standard conditions of temperature $\left(20-22^{\circ} \mathrm{C}\right)$ and lighting $(12 \mathrm{~h}$ light/dark cycle, lights on at 7:00 A.M.) with food and water available ad libitum. Rats were initially housed in groups of five to six for 3 weeks and then caged individually after surgery. Pregnant rats were obtained by mating overnight with a sexually experienced male, and the pregnancy was confirmed by finding a vaginal plug of semen on the floor of the breeding cage the following morning (day 1 of pregnancy; day 22 is the expected day of parturition). Virgin rats selected at random stages of the estrus cycle were used as controls. The number of rats per group for each experiment is given in the figure legends. All procedures were performed in accordance with current United Kingdom Home Office regulations and with University of Edinburgh Ethical Committee approval.

Surgery: jugular vein cannulation. Changes in ACTH and corticosterone secretion were assessed by collecting serial venous blood samples. Five days before the experiment, virgin and day 16 pregnant rats were fitted with a SILASTIC jugular vein cannula (wall, $0.25 \mathrm{~mm}$; internal diameter, $0.5 \mathrm{~mm}$; filled with sterile heparinized $0.9 \%$ saline, $50 \mathrm{U} / \mathrm{ml}$ ) under inhalational halothane anesthesia (2-3\% halothane, in $1200 \mathrm{ml} /$ min oxygen) for subsequent blood sampling and drug administration.

Blood sampling and tissue collection. On the morning of the experiment (between 7:30and 9:00 A.M.), the jugular cannula was connected to polyvinyl chloride extension tubing (wall, $1 \mathrm{~mm}$; internal diameter, $0.5 \mathrm{~mm}$ ) filled with heparinized saline ( $50 \mathrm{U} / \mathrm{ml} 0.9 \%$ saline) and attached to a 1 $\mathrm{ml}$ syringe, for remote sampling. Rats were then left undisturbed for 90 min. After collection of two basal blood samples (at $t=-31$ and -1 $\mathrm{min}$ ), rats were administered $500 \mathrm{ng} / \mathrm{kg}$ human recombinant IL- $1 \beta$ intravenously $(1 \mu \mathrm{g} / \mathrm{ml}$; dissolved in $0.2 \%$ bovine serum albumin in PBS; $t=0$ min; R \& D Systems). Additional blood samples were taken 15, 30, 60,90 , and $120 \mathrm{~min}$ after treatment. Blood samples $(0.35 \mathrm{ml})$ were collected into $1 \mathrm{ml}$ syringes containing $20 \mu \mathrm{l}$ of $5 \%$ EDTA, chilled on ice, and centrifuged to separate plasma, which was frozen and stored at $-20^{\circ} \mathrm{C}$ until assay. Each blood sample was replaced immediately with an equiv- alent volume of warmed sterile $0.9 \%$ saline. Rats were killed by conscious decapitation $4 \mathrm{~h}$ after IL- $1 \beta$ injection [the optimum time point for detecting peak changes in CRH mRNA expression after exposure to stress (Harbuz and Lightman, 1989)]. Trunk blood was collected into tubes containing chilled $5 \%$ EDTA $(0.2 \mathrm{ml} / 100 \mathrm{~g}$ body weight $)$, and plasma was separated and stored as above. Brains were rapidly removed, frozen on dry ice, and stored at $-70^{\circ} \mathrm{C}$ until sectioning. $\mathrm{CRH}$ neuron activation was evaluated by quantitative in situ hybridization (ISH) for CRH mRNA (see below). Pregnancy status was checked postmortem, and only pregnant rats with at least six viable fetuses were included in the study (actual range, $6-17$ pups; mode, 14 pups).

Experiment 1: is allopregnanolone involved in suppressing HPA axis responses in pregnant rats? To investigate a role for allopregnanolone in suppressed HPA axis responses to IL-1 $\beta$ in late pregnancy, allopregnanolone production was blocked using finasteride ( $5 \alpha$-reductase inhibitor). Blood samples and brains were collected (as above) from virgin and pregnant (day 21) rats treated with either finasteride $(25 \mathrm{mg} / \mathrm{kg}$, s.c.; Steraloids) or vehicle (15\% ethanol in sesame oil; $0.5 \mathrm{ml} / \mathrm{kg}$ ) 20 and $2 \mathrm{~h}$ before IL-1 $\beta(t=-20$ and $-2 \mathrm{~h})$. A separate group of pregnant (day 21) rats were treated with finasteride or vehicle (as above) only (no IL-1 $\beta$ ). Such finasteride treatment reduces brain allopregnanolone content by $90 \%$ in pregnant and $77 \%$ in nonpregnant rats, to similar actual levels (Concas et al., 1998).

Experiment 2: can the effects of pregnancy on HPA axis responses be mimicked in virgin rats with allopregnanolone treatment? To test whether suppressed HPA axis responses to IL- $1 \beta$ could be mimicked in virgin rats with allopregnanolone treatment, blood samples and brains were collected from virgin rats treated with AP (3 and $1 \mathrm{mg} / \mathrm{kg}$, s.c., 20 and $2 \mathrm{~h}$ before IL- $1 \beta$, respectively; Steraloids) or vehicle ( $15 \%$ ethanol in corn oil; $0.5 \mathrm{ml} / \mathrm{kg}$ ). To verify that the effects of finasteride on HPA responses to IL- $1 \beta$ seen in pregnant rats were attributable to the actions of allopregnanolone, blood samples and brains were also collected from pregnant (day 20-21) rats treated with finasteride (as before) and either allopregnanolone or vehicle (as above).

Experiment 3: can the allopregnanolone precursors suppress HPA axis responses in virgin rats? To establish whether administration of the allopregnanolone precursors progesterone or dihydroprogesterone (DHP) can restrain HPA axis responses to IL- $1 \beta$, virgin rats were treated with progesterone ( 20 and $4 \mathrm{mg} / \mathrm{kg}$, s.c., 20 and $2 \mathrm{~h}$ before IL- $1 \beta$, respectively; Steraloids) or vehicle (10\% benzyl alcohol and $0.3 \%$ cresol in arachis oil; $0.5 \mathrm{ml} / \mathrm{kg}$ ). A separate set of rats were treated with dihydroprogesterone ( 4 and $1 \mathrm{mg} / \mathrm{kg}$, s.c. 20 and $2 \mathrm{~h}$ before IL- $1 \beta$, respectively; Steraloids) or vehicle ( $15 \%$ benzyl alcohol and $0.3 \%$ cresol in arachis oil; $0.5 \mathrm{ml} / \mathrm{kg}$ ). In both cases, blood and brains were collected to evaluate HPA axis activity.

Experiment 4: does the expression of $m R N A$ for the allopregnanolonesynthesizing enzymes increase in the brain during pregnancy? To investigate whether mRNA expression for $5 \alpha$-reductase and/or $3 \alpha$-HSD is increased in the brain in pregnancy, untreated virgin and pregnant (day 21) rats were killed by conscious decapitation. Brains, brainstems, and liver (positive control) were removed, frozen on dry ice, and stored at $-70^{\circ} \mathrm{C}$ until processing for ISH.

Experiment 5: are the activities of the allopregnanolone-synthesizing enzymes increased in the brain during pregnancy? To investigate whether the activity of $5 \alpha$-reductase and/or $3 \alpha$-HSD is increased in the brain in pregnancy, untreated virgin and pregnant (day 21) rats were killed by conscious decapitation. Brains were removed, and the hypothalamus (cut rostrocaudally between the optic chiasm and mammillary bodies, laterally at the hypothalamic sulci and dorsally below the ventral thalamus) and medulla oblongata [bregma, -10 to $-15 \mathrm{~mm}$ (Paxinos and Watson, 1998)] were dissected, frozen on dry ice, and stored at $-70^{\circ} \mathrm{C}$ until subsequent enzyme assay.

Experiment 6: are the effects of allopregnanolone and endogenous opioids in pregnant rats interdependent? Pregnant rats (day 21) were pretreated with either vehicle or finasteride (as before). Immediately after the first basal blood sample was collected, rats were given either naloxone [5 $\mathrm{mg} / \mathrm{kg}$, i.v.; naloxone was used at this dose as a nonselective opioid receptor antagonist, as before (Brunton et al., 2005), because the opioid receptor type that mediates opioid inhibition of HPA axis in pregnancy has not been defined] or vehicle $(0.9 \%$ saline, $0.5 \mathrm{ml} / \mathrm{kg})$. After an addi- 
Table 1. Oligonucleotide probe sequences for specific mRNA hybridization

\begin{tabular}{|c|c|c|}
\hline Probe & Length & Sequence \\
\hline $\mathrm{CRH}$ & 42-mer & 5' -CCT GTT GCT GTG AGC TTG CTG AGC TAA CTG CTCTGC CCT GCC-3' \\
\hline pENK-A & 39-mer & 5'-TGC ATC CTT CTT CAT GAA ACC GCC ATA CCT CTTGGC AAG-3' \\
\hline POMC & 45-mer & 5'-CAT GAA GCC GCC GTA GCG CTT GTC CTT GGG CGGGTT GCC CCA GCG-3' \\
\hline$\mu-0 R$ & 45-mer & $5^{\prime}-\mathrm{GAA} A C C$ AGA GCC TCC CAC ACA CCC TGA CAG CAACCT GAT TCC ACG-3' \\
\hline
\end{tabular}

tional two blood samples 15 and 30 min later, all rats were given IL-1 $\beta$ (as before). Additional blood samples were taken 15, 30, 60, 90, and $120 \mathrm{~min}$ after IL- $1 \beta$, rats were killed at $4 \mathrm{~h}$ (as before), and brains were collected to assess CRH neuron activation by quantitative ISH for CRH mRNA. One group of control virgin rats were given oil vehicle and saline pretreatment before IL- $1 \beta$ and sampled as above. Separate groups of virgin and pregnant rats were blood sampled after treatment with only naloxone (i.e., with no subsequent IL- $1 \beta$ treatment) or saline.

Experiment 7: can allopregnanolone induce opioid inhibition over HPA axis responses in virgin rats? To establish whether allopregnanolone exerts its effects on HPA responsiveness by inducing inhibitory opioid tone, virgin rats were given either allopregnanolone or vehicle (as before). Immediately after the first basal blood sample was taken, rats were given either naloxone $(5 \mathrm{mg} / \mathrm{kg}$, i.v.) or vehicle $(0.9 \%$ saline, $0.5 \mathrm{ml} / \mathrm{kg})$. After an additional two blood samples 15 and $30 \mathrm{~min}$ later, all rats were given IL-1 $\beta$ (as before). Additional blood samples were taken 15, 30, 60, 90, and $120 \mathrm{~min}$ after IL-1 $\beta$, rats were killed at $4 \mathrm{~h}$ (as before), and brains were collected to assess $\mathrm{CRH}$ neuron activation by quantitative ISH for CRH mRNA.

Experiment 8: does allopregnanolone alter central opioid expression? To investigate whether allopregnanolone upregulates central opioid expression virgin rats were treated with allopregnanolone or vehicle (as in experiment 2). Late pregnant rats were treated with finasteride or vehicle (as in experiment 1). Two hours after the second injection, rats were killed by conscious decapitation. Expression of pENK-A, proopiomelanocortin (POMC), and MOR mRNAs in selected nuclei in the hypothalamus and brainstem were evaluated by quantitative ISH.

Radioimmunoassays. ACTH concentrations were determined in unextracted plasma using a commercially available two-site immunoradiometric kit (Euro-diagnostica), whereas corticosterone (IDS Ltd.) and progesterone (Diagnostic Systems Laboratories) were measured using radioimmunoassay kits. The sensitivity and intra-assay variation for each of the assays were as follows: ACTH: sensitivity, $1 \mathrm{pg} / \mathrm{ml}$ and intra-assay variation, $<7 \%$; corticosterone: sensitivity, $0.4 \mathrm{ng} / \mathrm{ml}$ and intra-assay variation $<8 \%$; progesterone: sensitivity, $0.3 \mathrm{ng} / \mathrm{ml}$ and intra-assay variation $<6 \%$. All samples from any one experiment were assayed together.

In situ hybridization. Tissue was sectioned coronally on a cryostat at 15 $\mu \mathrm{m}$ and thaw mounted onto Polysine slides. All sections from a particular experiment were processed in the same hybridization reaction. ${ }^{35} \mathrm{~S}$ Radiolabeled oligonucleotide probes (MWG-Biotech) were used to detect CRH, pENK-A, POMC, and $\mu$-opioid receptor mRNA expression. The sequences of each oligonucleotide probe are given in Table 1 and in situ hybridization using these probes was performed as described previously (Brunton et al., 2005).

$\left[{ }^{35} \mathrm{~S}\right]$ UTP-labeled cRNA sense and antisense probes were synthesized from the linearized pBluescript SK - vector expressing a $344 \mathrm{bp}$ (nucleotides 991-1334) cDNA fragment encoding rat $5 \alpha$-reductase type I the predominant isoform expressed in adult brain (Compagnone and Mellon, 2000; Sánchez et al., 2008a,b); generously provided by Prof. Marcel Karperien, Leiden University Medical Center, Leiden, The Netherlands]. The plasmid was linearized with XhoI and XbaI and transcribed using T3 and T7 polymerase (Promega) for the sense and antisense riboprobes, respectively. To detect $3 \alpha$-HSD mRNA, $\left[{ }^{35}\right.$ S ]UTP-labeled sense and antisense riboprobes were generated from the linearized pGEM3 vector expressing a 982 bp (nucleotides -129 to +853) cDNA fragment encoding rat $3 \alpha$-HSD (generously provided by Prof. Trevor Penning, University of Pennsylvania, Philadelphia, PA). The plasmid was linearized with SalI and SspI, and sense and antisense cRNAs incorporating $\left[{ }^{35}\right.$ S]UTP were transcribed from the T7 and SP6 promoters, respectively.

For in situ hybridization using riboprobes, tissue was first fixed in $4 \%$ paraformaldehyde, acetylated in triethanolamine/acetic anhydride solution, and then partially dehydrated in ethanol before incubation in prehybridization buffer [ $50 \%$ deionized formamide (v/v), $1 \times$ Denhardt's solution, $1 \mathrm{~mm}$ EDTA, $0.5 \mathrm{mg} / \mathrm{ml}$ salmon testes DNA, $600 \mathrm{~mm}$ sodium chloride, $10 \mathrm{~mm}$ Tris, and $125 \mu \mathrm{g} / \mathrm{ml}$ yeast tRNA] at $50^{\circ} \mathrm{C}$ for $120 \mathrm{~min}$. Riboprobes incorporating ${ }^{35} \mathrm{~S}$-labeled UTP were mixed with hybridization buffer [50\% deionized formamide $(\mathrm{v} / \mathrm{v}), 1 \times$ Denhardt's solution, $10 \%$ dextran sulfate $(\mathrm{w} / \mathrm{v}), 15$ mu dithiothreitol, $1 \mathrm{~mm}$ EDTA, $0.1 \mathrm{mg} / \mathrm{ml}$ salmon testes DNA, $600 \mathrm{~mm}$ sodium chloride, $10 \mathrm{~mm}$ Tris, and $125 \mu \mathrm{g} / \mathrm{ml}$ yeast tRNA], heated for 10 min at $70^{\circ} \mathrm{C}$, quenched on ice, and applied to the tissue $(650,000 \mathrm{cpm} /$ section). To aid tissue penetration, the radiolabeled $3 \alpha$-HSD riboprobe was fragmented by alkaline hydrolysis and neutralized before hybridization. Sections were hybridized at $55^{\circ} \mathrm{C}$ and $60^{\circ} \mathrm{C}$ (for $5 \alpha$-reductase and $3 \alpha$-HSD mRNAs, respectively) for 18-19 h. Sections of rat liver treated as above were used as positive controls. Brain and liver sections serving as negative controls to ensure probe specificity were hybridized with $\left[{ }^{35} \mathrm{~S}\right] \mathrm{UTP}$-labeled cRNA sense probes. The hybridization signal over tissue hybridized with the sense probe was not different from background.

After hybridization, the slides were rinsed briefly (to remove coverslips) in $2 \times$ SSC and then washed three times for $5 \mathrm{~min}$ in $2 \times$ SSC at room temperature. Next, sections were incubated in buffer ( 1 mM EDTA $500 \mathrm{~mm}$ sodium chloride, and $10 \mathrm{~mm}$ Tris) containing $15 \mu \mathrm{g} / \mathrm{ml}$ RNase A for $60 \mathrm{~min}$ at $37^{\circ} \mathrm{C}$. Sections were then briefly rinsed in $2 \times$ SSC at room temperature before additional stringency washing (for $5 \alpha$-reductase, once in $2 \times \mathrm{SSC}$ at $37^{\circ} \mathrm{C}$ and twice at $55^{\circ} \mathrm{C}$ for $30 \mathrm{~min}$ each, followed by two 60 min washes in $0.2 \times$ SSC at $55^{\circ} \mathrm{C}$; and for $3 \alpha$-HSD, 60 min each in $2 \times$ SSC at $50^{\circ} \mathrm{C}$ and in $0.2 \times$ SSC at $55^{\circ} \mathrm{C}$ and then $60^{\circ} \mathrm{C}$ ). After the posthybridization washes, tissue was dehydrated in an ascending series of ethanol containing $300 \mathrm{~mm}$ ammonium acetate, air dried, dipped in autoradiographic emulsion (Ilford K-5), and exposed at $4^{\circ} \mathrm{C}$. Exposure times for each mRNA species were as follows: CRH, 10 weeks; $3 \alpha$-HSD, 10 weeks; pENK-A, 6 weeks; POMC, 5 weeks; $\mu$-opioid receptor, 6 weeks; and $5 \alpha$-reductase, 7 weeks.

Slides were developed (Kodak D-19; Sigma), fixed (Hypam rapid fixer; Ilford), and counterstained with hematoxylin and eosin. Autoradiographs were quantified using three methods. (1) The area of each region of interest (e.g., PVN or NTS) and the silver grain area overlying the region were measured (NIH Image software, version 1.62) and are presented as grain area/brain area $\left(\mathrm{mm}^{2} / \mathrm{mm}^{2}\right)$. Background measurements were made over areas adjacent to the region of interest and subtracted. (2) The number of cells positively hybridized in a particular brain region was counted manually in emulsion-dipped sections. A positive cell was defined as one with more overlying silver grains than the mean over 10 cells lateral to the region of interest (background) +3 SDs. Data are presented as the number of positive cells per brain area $\left(\mathrm{mm}^{2}\right)$. (3) Grain density per cell data were determined by measuring the silver grain area over $\sim 240$ cells per area per rat (Openlab version 2 software; Improvision). Background measurements were made over equivalently sized cells in the neuropil adjacent to the region of interest and subtracted. In each case, measurements were made over a minimum of 12 PVN or NTS profiles (bilateral measurements in six consecutive sections). Integrated density was calculated by multiplying the mean number of positive neurons in a specific brain region section by the mean grain area per cell (data given in arbitrary units). For all ISH measurements, average values for each rat were used to calculate group means \pm SEM.

Enzyme assays and thin-layer chromatography. Brain tissue was weighed, and a $10 \%(\mathrm{w} / \mathrm{v})$ homogenate $(\sim 12.5 \mathrm{mg}$ protein $/ \mathrm{ml})$ was prepared in buffer, $\mathrm{pH} 7.22$, containing $100 \mathrm{~mm}$ potassium phosphate, $1 \mathrm{~mm}$ EDTA, and $0.32 \mathrm{M}$ sucrose using a glass homogenizer. Protein concentration of the homogenates was measured using the Bradford protein assay. Homogenates were preincubated at $37^{\circ} \mathrm{C}$ for $10 \mathrm{~min}$ in $100 \mathrm{~mm}$ potassium phosphate buffer containing $50 \mu \mathrm{M}$ EDTA, $5 \mathrm{~mm}$ dithiothreitol, and the appropriate cofactor ( $100 \mu \mathrm{M}$ NADPH for $5 \alpha$-reductase and $100 \mu \mathrm{M}$ NADPH and $100 \mu \mathrm{M}$ NADH for $3 \alpha$-HSD) before addition of 20 $\mu \mathrm{Ci}\left[1,2,6,7-{ }^{3} \mathrm{H}(\mathrm{N})\right]$-progesterone (specific activity, $115 \mathrm{Ci} / \mathrm{mmol}$ ). The 
preparations were incubated in a shaking water bath for $40 \mathrm{~min}$ at $37^{\circ} \mathrm{C}$. Control reactions were included for each assay and contained all of the components (given above) except for the tissue homogenate. The reaction was terminated by transferring the tubes to ice and by the addition of ice-cold methanol/chloroform (1:1). Tubes were agitated for $5 \mathrm{~min}$, and the different phases were separated by centrifugation ( $6000 \mathrm{rpm}$ for $1 \mathrm{~min})$. Progesterone metabolites were separated by thin-layer chromatography (TLC) using silica gel $60 \mathrm{~F}_{254}$ TLC plates $(20 \times 20 \mathrm{~cm}$; Merck) previously activated by heating at $100^{\circ} \mathrm{C}$ for $15 \mathrm{~min}$. Fifty microliters of each extract or unlabeled standard $[1 \mathrm{mg} / \mathrm{ml}(\mathrm{w} / \mathrm{v})$ progesterone, dihydroprogesterone, and allopregnanolone in ethanol] were spotted onto the bottom right-hand corner of the TLC plates. Each plate was run in a two-dimensional system: twice in solvent system 1 (benzene/methanol, 19:1, v/v), then plates were turned $90^{\circ}$ and run twice in solvent system 2 (cyclohexane/ ethylacetate, 1:2, v/v). Steroids were visualized by first exposing the TLC plates to $30 \% \mathrm{H}_{2} \mathrm{SO}_{4}$ in ethanol, heating to $140^{\circ} \mathrm{C}$ for $15 \mathrm{~min}$, and then by ultraviolet illumination. The spots corresponding to the substrate (progesterone) and metabolites were scraped from the plates and the radioactivity counted in a $\beta$-scintillation counter. The quantity of the metabolites converted from progesterone is expressed as a percentage of the total radioactivity and is indicative of the enzyme activities.

Statistical analysis. SigmaStat (version 3.1; Systat Software) and SPSS software (version 17; SPSS) were used to analyze the data. The specific statistical tests used are given in Results. Data from in situ hybridization studies and enzyme activity data were analyzed by ANOVA or Student's $t$ test; when we had predicted direction of change, a one-tailed Student's $t$ test was used. To analyze the effects of treatment across time in plasma hormone data, two-way repeated measures ANOVA (two-way RM ANOVA) (SigmaStat) were used when there were two treatment groups. In cases in which

three or more treatment groups were to be analyzed, a repeated measures mixed-model ANOVA (mixed ANOVA) (SPSS) was used, followed by a two-way RM ANOVA to critically test our original hypotheses with planned comparisons when appropriate. Specific differences were isolated using Student-Newman-Keuls (SNK) multiple comparison post hoc tests. In each case, values shown are group means \pm SEM. $p$ values $<0.05$ were considered statistically significant.

\section{Results}

Effect of blocking allopregnanolone production on HPA axis responses to IL-1 $\beta$

There was a significant effect of pregnancy $\left(F_{(1,23)}=12.0, p=\right.$ 0.002 , mixed ANOVA $)$ and time $\left(F_{(1,23)}=43.7, p<0.0001\right)$ on plasma ACTH responses to IL-1 $\beta$ (Fig. 1a). Within the virgin groups ("virgin"), finasteride ("FIN") treatment had no significant effect on plasma ACTH concentration $\left(F_{(1,84)}=0.675, p=\right.$ 0.427 , two-way RM ANOVA), but there was a significant effect of finasteride treatment within the pregnant groups ("preg") $\left(F_{(1,77)}\right.$ $=7.547, p=0.019$, two-way RM ANOVA). Basal plasma ACTH concentrations did not differ between virgin and pregnant rats pretreated with vehicle ("veh") or finasteride (Fig. 1a). IL-1 $\beta$ significantly increased ACTH secretion (3.2-fold; $p<0.001$, SNK b) Corticosterone

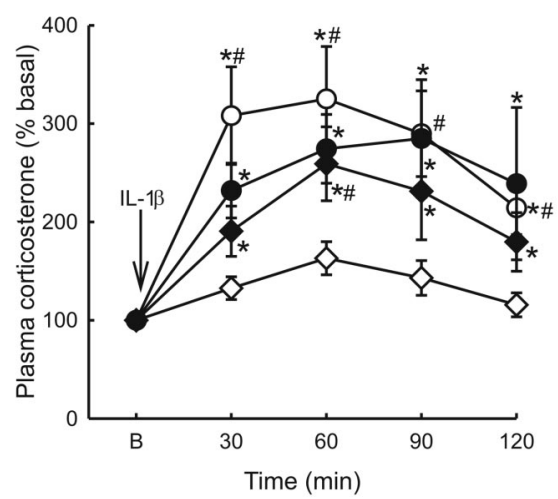

d) $\mathrm{CRH}$ mRNA
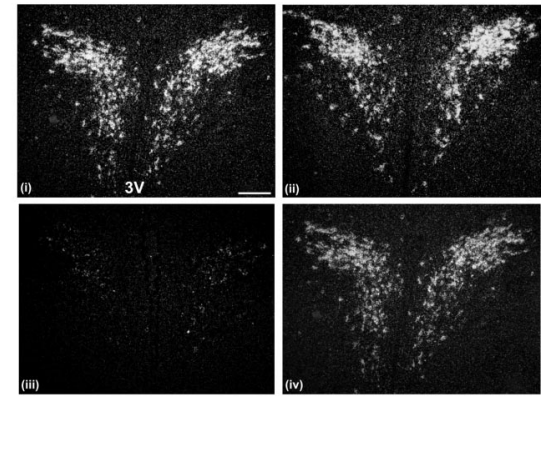

Figure 1. Effect of inhibiting allopregnanolone synthesis on HPA axis responses to IL- $1 \beta$ in virgin and pregnant rats. Virgin and day 21 pregnant (preg) rats were treated with either finasteride (FIN; $25 \mathrm{mg} / \mathrm{kg}$, s.c.) or vehicle (veh) 20 and $2 \mathrm{~h}$ before IL- $1 \beta$. After two basal (B) blood samples (at $t=-31$ and $-1 \mathrm{~min})$, all rats were administered IL-1 $\beta(500 \mathrm{ng} / \mathrm{kg}$, i.v.) at $t=0$ min. Additional blood samples were taken $15,30,60,90$, and 120 min after treatment. Trunk blood was collected at $t=240$ min. $n=6-7$ rats 作 reg/veh group at the same time point. Rats were killed $4 \mathrm{~h}$ after IL-1 $\beta$ administration, and brains were processed by in situ (2) PPVN. CRH mRNA expression levels [expressed as arbitrary units Trats per group. ${ }^{*} p<0.001$ versus virgin/veh group; ${ }^{\#} p<0.003$ versus virgin/FIN group; ${ }^{+} p<0.05$ versus preg/veh group. Values are group means \pm SEM. $\boldsymbol{d}$, CRH mRNA: representative dark-field autoradiographs of coronal PVN sections from the following: $\boldsymbol{i}$, virgin/vehicle; ii, virgin/FIN; iii, pregnant/vehicle; and iv, pregnant/FIN. 3V, Third ventricle. Scale bar, $200 \mu \mathrm{m}$.

test) in the vehicle-pretreated virgin rats, but IL- $1 \beta$ had no significant effect in the vehicle-pretreated pregnant rats $(p=0.839$, SNK test). Finasteride pretreatment had no effect on the amplitude of the ACTH response to IL- $1 \beta$ in virgin rats. In late pregnant rats, finasteride significantly restored an ACTH response to IL- $1 \beta$ ( $p=0.002$ vs basal levels, SNK test) to $77 \%$ at peak of that observed in vehicle-treated virgin rats.

There was a significant effect of pregnancy $\left(F_{(1,20)}=6.0, p=\right.$ 0.023 , mixed ANOVA) on plasma corticosterone concentrations (Fig. 1b). Finasteride treatment had no significant effect on plasma corticosterone concentration within the virgin groups $\left(F_{(1,44)}=0.176, p=0.683\right.$, two-way RM ANOVA), but there was a significant effect of finasteride treatment within the pregnant groups $\left(F_{(1,42)}=4.922, p=0.048\right)$. Basal plasma corticosterone concentration was greater in the pregnant rats (this only reached statistical significance in the preg/veh group; $p=0.02$, SNK test), but finasteride treatment had no effect in either virgin or pregnant rats (basal plasma corticosterone concentrations: virgin/ veh, $50.1 \pm 5.3 \mathrm{ng} / \mathrm{ml}$; virgin/FIN, $54.3 \pm 6.5 \mathrm{ng} / \mathrm{ml}$; $\mathrm{preg} / \mathrm{veh}$, $159.9 \pm 27.6 \mathrm{ng} / \mathrm{ml} ; \mathrm{preg} / \mathrm{FIN}, 120.4 \pm 17.5 \mathrm{ng} / \mathrm{ml})$. As expected, IL-1 $\beta$ significantly increased plasma corticosterone concentra- 

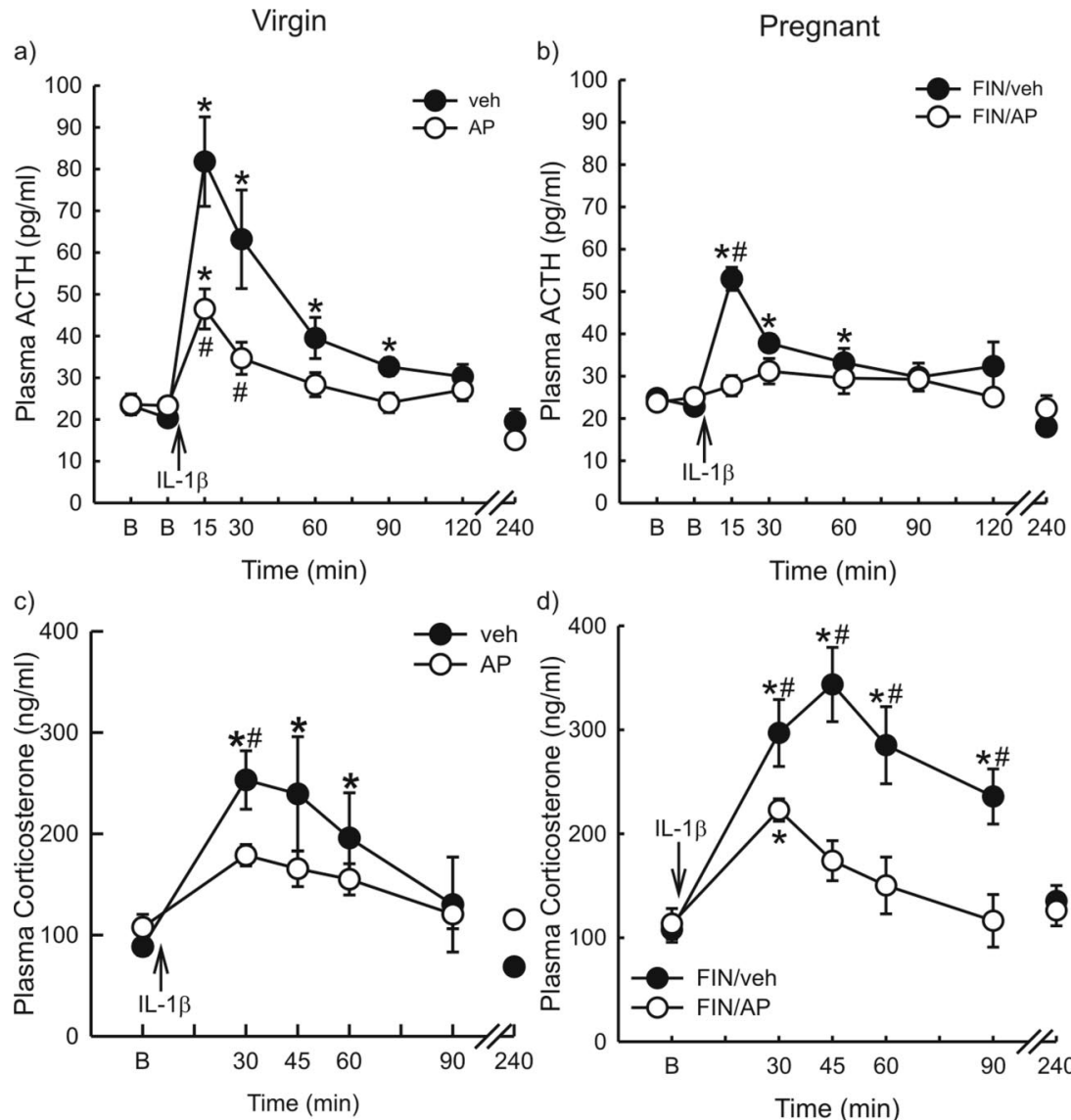

d)
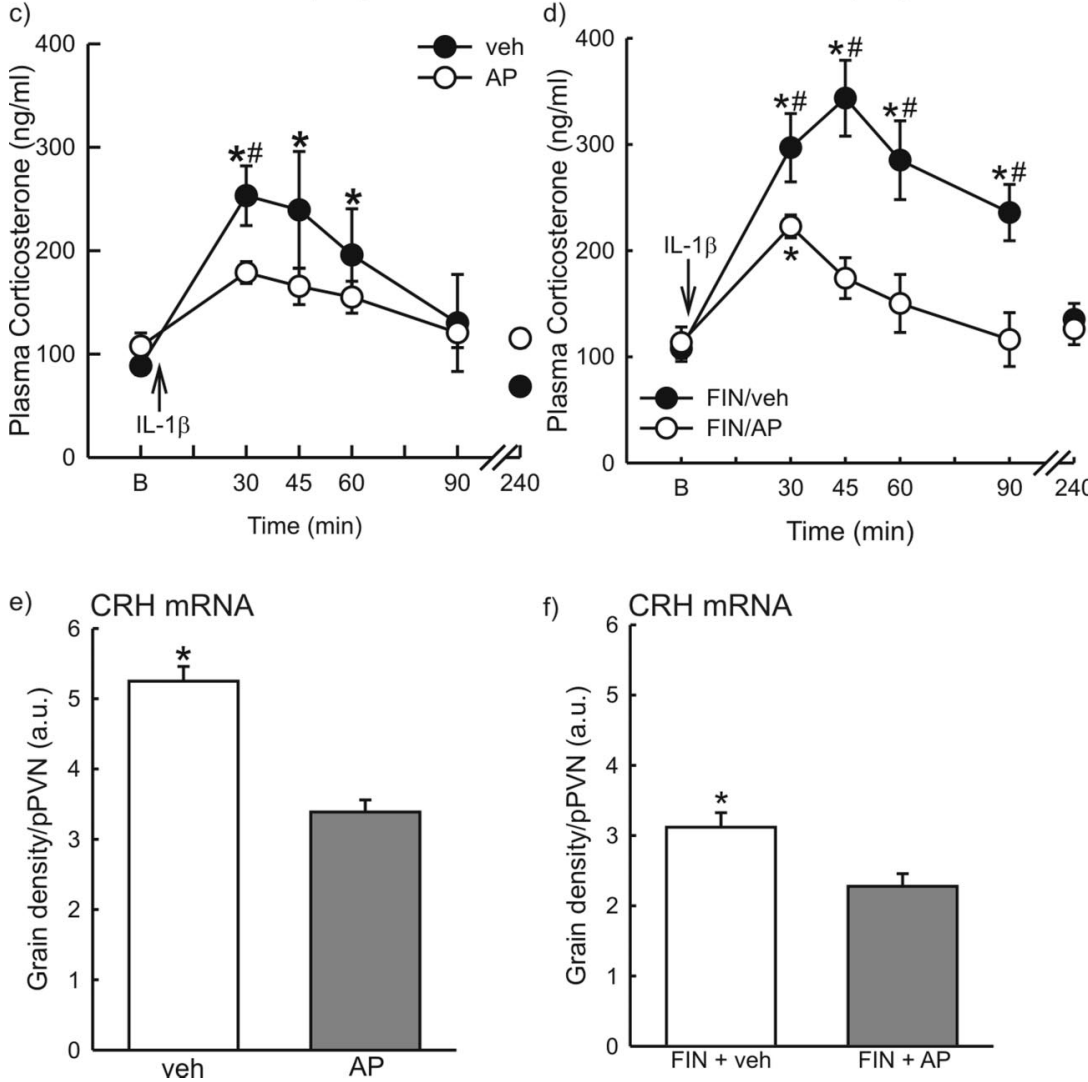

Figure 2. Effect of allopregnanolone treatment on HPA axis responses to IL-1 $\beta$. Virgin rats $(\boldsymbol{a}, \boldsymbol{c}, \boldsymbol{e})$ were treated with allopregnanolone ( 3 and $1 \mathrm{mg} / \mathrm{kg}$, S.C., 20 and $2 \mathrm{~h}$ before IL-1 $\beta$, respectively) or vehicle (veh), whereas pregnant (day $20-21$ ) rats (b, $\boldsymbol{d}, \boldsymbol{f})$ were treated with finasteride $(25 \mathrm{mg} / \mathrm{kg}, \mathrm{s} . \mathrm{c}$.) and either allopregnanolone (as above) or vehicle 20 and $2 \mathrm{~h}$ before $\mathrm{lL}-1 \beta$. After two basal (B) blood samples (at $t=-31$ and $-1 \mathrm{~min}$ ), all rats were administered IL- $1 \beta(500 \mathrm{ng} / \mathrm{kg}$, i.v.) at $t=0 \mathrm{~min}$. Additional blood samples were taken $15,30,60,90$, and $120 \mathrm{~min}$ after treatment. Trunk blood was collected at $t=240 \mathrm{~min}$. Plasma ACTH concentrations in virgin $(\boldsymbol{a})$ and pregnant $(\boldsymbol{b})$ rats. $\boldsymbol{c}, \boldsymbol{d}$, Plasma corticosterone concentrations in virgin $(\boldsymbol{c})$ and pregnant $(\boldsymbol{d})$ rats. $n=5-7$ rats per group. $\boldsymbol{a},{ }^{*} p<0.03$ versus basal values in the same group; ${ }^{\#} p<0.04$ versus virgin/veh group; $\boldsymbol{b},{ }^{*} p<0.05$ versus basal values in the same group; ${ }^{*} p<0.001$ versus preg/FIN/AP group; $\boldsymbol{c}, \boldsymbol{d},{ }^{*} p<0.001$ versus basal values in the same group; $" \#<0.04$ versus other group at the same time point. Rats were killed $4 \mathrm{~h}$ after IL-1 $\beta$ administration, and brains were processed by in situ hybridization. $\boldsymbol{e}, \boldsymbol{f}$, Quantification of CRH mRNA expression in the PPVN in brains from virgin $(\boldsymbol{e})$ and pregnant $(f)$ rats. Grain density per pPVN profile [expressed as arbitrary units (a.u.)] was calculated by multiplying the mean grain density per neuron by the mean number of neurons positively expressing CRH mRNA. $n=6-9$ rats per group. $\boldsymbol{e}^{*}{ }^{*} p<0.001$ versus virgin/AP group; $\boldsymbol{f},{ }^{*} p<0.02$ versus $\mathrm{preg} /$ FIN/AP group. All values are group means \pm SEM.

tions in the vehicle-treated virgin but not pregnant rats (Fig. $1 b$ ) $(p<0.001$, SNK test). Finasteride pretreatment had no significant effect on the corticosterone response to IL- $1 \beta$ in the virgin rats, but it resulted in a significant corticosterone response in the late pregnant rats (Fig. $1 b$ ).
Treatment with finasteride alone (i.e., no IL-1 $\beta$ ) had no significant effect on basal CRH mRNA expression in the pPVN of late pregnant rats (grain area per pPVN was $0.055 \pm 0.013 \mathrm{~mm}^{2} / \mathrm{mm}^{2}$ in vehicletreated rats, $n=6$ vs $0.050 \pm 0.019 \mathrm{~mm}^{2} /$ $\mathrm{mm}^{2}$ in finasteride-treated rats, $n=4 ; p>$ 0.05 , two-tailed Student's $t$ test). There was, however, a significant effect of both pregnancy $\left(F_{(1,18)}=34.5, p<0.001\right.$, twoway ANOVA) and finasteride treatment $\left(F_{(1,18)}=7.3, p=0.015\right)$ on CRH mRNA expression in the pPVN after IL- $1 \beta$ administration. In vehicle-treated pregnant rats, CRH mRNA expression in the pPVN was significantly less $4 \mathrm{~h}$ after systemic IL- $1 \beta$ than in the vehicle-treated virgin group (Fig. $1 c, d$ ). Finasteride had no effect on CRH mRNA expression after IL- $1 \beta$ in the virgin rats, but it resulted in a significant increase in expression in the late pregnant rats (Fig. 1c,d).

Effect of allopregnanolone treatment on HPA axis responses to IL-1 $\beta$

There was a significant effect of allopregnanolone treatment $\left(F_{(1,66)}=13.2, p=\right.$ 0.003, two-way RM ANOVA) on ACTH secretion in the virgin rats (Fig. 2a). There was no difference in basal plasma ACTH concentration between vehicle and allopregnanolone-pretreated virgin rats (Fig. 2a). IL- $1 \beta$ significantly increased ACTH secretion within $15 \mathrm{~min}$ in both the vehicle-treated virgins (4.0-fold increase; $p<0.001$, SNK test) and the allopregnanolone treated virgins (2.0-fold increase; $p<0.001$ ); however, the response was markedly reduced in the allopregnanolone-treated group $(57 \%$ of the peak response in the vehicle group; $p<$ 0.001 ).

There was also a significant effect of allopregnanolone treatment on corticosterone secretion in the virgin rats $\left(F_{(1,51)}=\right.$ $5.1, p=0.028$, two-way RM ANOVA) (Fig. 2c). Consistent with the ACTH data, basal corticosterone secretion was not significantly different between the vehicleand allopregnanolone-treated virgins ( Fig. $2 c$ ), but the IL- $1 \beta$-evoked increase in corticosterone secretion was significantly attenuated in the allopregnanolone-treated group (Fig. 2c).

In the late pregnant rats, there was a significant effect of drug treatment $\left(F_{(1,58)}\right.$ $=6.2, p=0.034$, two-way RM ANOVA) on plasma ACTH concentration (Fig. 2b). Neither finasteride alone nor combined finasteride and allopregnanolone treatment affected basal plasma ACTH concentration in late pregnant rats (Fig. 2b). As before, blocking allopregnanolone production with finasteride restored a significant ACTH response to IL- $1 \beta$ in late pregnant rats (Fig. $2 b$ ). This 
effect was prevented in the pregnant rats by coadministration of allopregnanolone.

There was a significant effect of drug treatment $\left(F_{(1,40)}=20.6, p=0.002\right.$, twoway RM ANOVA) on corticosterone secretion in the pregnant rats. Accordingly, finasteride treatment restored a corticosterone response to IL- $1 \beta$ in late pregnant rats (Fig. $2 d$ ), which was attenuated by combined allopregnanolone treatment.

CRH mRNA expression in the pPVN $4 \mathrm{~h}$ after systemic IL- $1 \beta$ was significantly less in virgin rats pretreated with allopregnanolone compared with those pretreated with vehicle (Fig. $2 e)(p<0.001$, one-tailed Student's $t$ test). Furthermore, CRH mRNA expression in the pPVN 4 h after systemic IL- $1 \beta$ was significantly less in pregnant rats treated with a combination of finasteride and allopregnanolone compared with pregnant rats treated with finasteride alone (Fig. $2 f)(p=0.01)$. Treatment of virgin rats with allopregnanolone only for $20 \mathrm{~h}$ had no effect on basal CRH mRNA expression in the pPVN (Table 2).

\section{Effect of progesterone or}

dihydroprogesterone on HPA axis responses to $I L-1 \beta$ in virgin rats

As expected, subcutaneous progesterone injections significantly increased plasma progesterone concentrations (before injection, $11.9 \pm 1.1 \mathrm{ng} / \mathrm{ml}$ vs after injection, $54.6 \pm 7.5 \mathrm{ng} / \mathrm{ml} ; F_{(1,22)}=18.3, p<0.001$, two-way RM ANOVA). There was no significant effect of progesterone treatment on either plasma ACTH (Fig. $3 a$ ) or corticosterone concentrations (Fig. 3b), but there was a significant effect of IL- $1 \beta$ administration on $\operatorname{ACTH}\left(F_{(7,56)}=11.4, p<\right.$ $0.001)$ and corticosterone $\left(F_{(5,39)}=9.6\right.$, $p<0.001)$ secretion. Systemic IL- $1 \beta$ significantly increased both plasma ACTH (Fig. 3a) and corticosterone (Fig. 3b) concentrations compared with basal levels in the vehicle- and progesterone-treated rats, but there were no differences between groups. Furthermore, progesterone pretreatment had no significant effect on CRH mRNA expression in the pPVN after IL- $1 \beta$ (grain area was $0.27 \pm 0.03 \mathrm{~mm}^{2} / \mathrm{mm}^{2}$ in the vehicle group vs $0.26 \pm 0.03 \mathrm{~mm}^{2} /$ $\mathrm{mm}^{2}$ in the progesterone group; $p=0.757$, two-tailed Student's $t$ test).

DHP treatment had no significant effect on either plasma ACTH (Fig. 3c) or corticosterone (Fig. $3 d$ ) concentrations, but IL- $1 \beta$ administration did have a significant effect (two-way RM ANOVA: ACTH, $F_{(7,71)}=18.4, p<0.001$; corticosterone, $F_{(5,47)}$ $=5.7, p=0.001$ ). IL- $1 \beta$ increased plasma ACTH (Fig. $3 c$ ) and corticosterone (Fig. $3 d$ ) concentrations similarly in the vehicleand DHP-treated virgin rats. As with progesterone, DHP treatment had no significant effect on $\mathrm{CRH}$ mRNA expression in the pPVN after IL- $1 \beta$ (grain area was $0.20 \pm 0.03 \mathrm{~mm}^{2} / \mathrm{mm}^{2}$ in the
Table 2. Virgin rats were treated with AP ( 3 and $1 \mathrm{mg} / \mathrm{kg}$, s.c.) or veh at $t=-20$ and $-2 \mathrm{~h}$ and then killed by conscious decapitation at $t=0 \mathrm{~h}$ ( $n=6-7$ rats per group).

\begin{tabular}{lllllll}
\hline & & \multicolumn{2}{l}{ Vehicle } & & & \\
mRNA & Brain region & \#Positive cells & Grain density per cell $\left(\mu \mathrm{m}^{2}\right)$ & & \# Positive cells & Grain density per cell $\left(\mu \mathrm{m}^{2}\right)$ \\
\hline pENK-A & NTS A2 & $115 \pm 3$ & $34.0 \pm 0.3$ & $141 \pm 10^{*}$ & $38.4 \pm 0.9^{* *}$ \\
pENK-A & mgPVN & $21.8 \pm 4.9$ & $45.1 \pm 1.0$ & $17.5 \pm 3.6$ & $45.6 \pm 1.0$ \\
pENK-A & Arc & $46.5 \pm 4.5$ & $30.6 \pm 0.5$ & $51.2 \pm 1.3$ & $30.9 \pm 0.4$ \\
POMC & Arc & $46.8 \pm 2.7$ & $19.0 \pm 0.4$ & $47.0 \pm 1.9$ & $18.9 \pm 0.4$ \\
MOR & NTS A2 & $117.1 \pm 12.2$ & $19.2 \pm 0.6$ & $108.5 \pm 7.5$ & $18.6 \pm 0.7$ \\
CRH & pPVN & $131.1 \pm 11.7$ & $49.3 \pm 6.6$ & $131.1 \pm 6.9$ & $44.6 \pm 3.5$ \\
\hline
\end{tabular}

$\mathrm{mg}$ PVN, Magnocellular subdivision of the paraventricular nucleus; Arc, arcuate nucleus. ${ }^{*} p<0.02,{ }^{* *} p<0.001$ versus veh group. Values are mean \pm SEM.
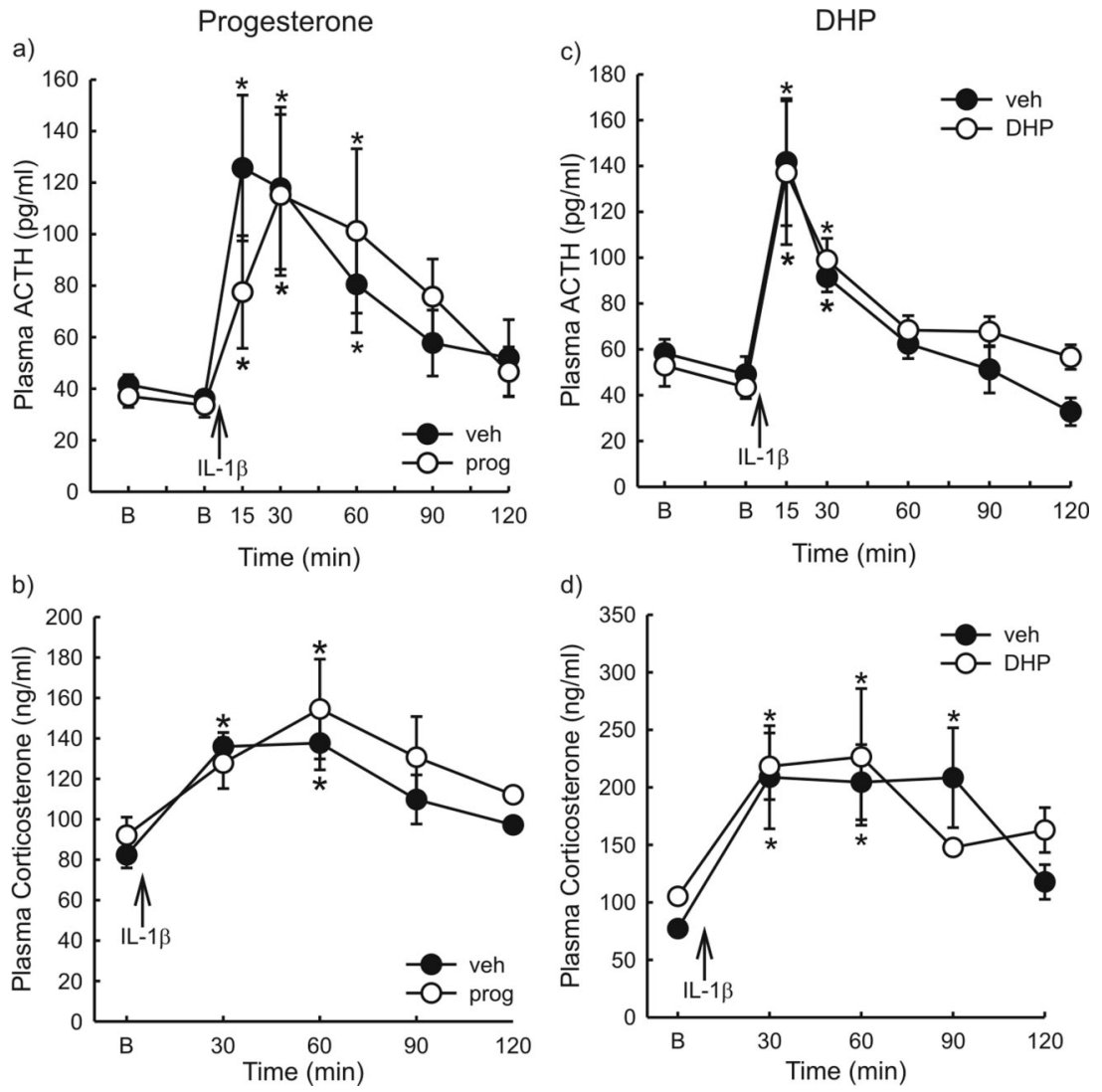

Figure 3. Effect of progesterone or dihydroprogesterone treatment on HPA axis responses to IL-1 $\beta$ in virgin rats. $\boldsymbol{a}, \boldsymbol{b}$, Virgin rats were treated with either progesterone ( $p r o g ; 20$ and $4 \mathrm{mg} / \mathrm{kg}$, s.c., 20 and $2 \mathrm{~h}$ before IL-1 $\beta$, respectively) or vehicle 20 and $2 \mathrm{~h}$ or vehicle (veh) 20 and $2 \mathrm{~h}$ before IL-1 $\beta$. After two basal blood samples ( $\mathrm{B}$; at $t=-31$ and $-1 \mathrm{~min}$ ), all rats were administered per group. Values are group means \pm SEM. Plasma ACTH concentration ( $\boldsymbol{a})$ and plasma corticosterone concentration $(\boldsymbol{b})$ before and after systemic IL-1 $\beta$ in vehicle- and progesterone-treated virgin rats. Plasma ACTH concentration (c) and plasma corticosterone concentration $(\boldsymbol{d})$ before and after systemic IL-1 $\beta$ in vehicle- and DHP-treated virgin rats. ${ }^{*} p<0.05$ versus basal.

vehicle group vs $0.29 \pm 0.04 \mathrm{~mm}^{2} / \mathrm{mm}^{2}$ in the DHP group; $p=$ 0.08 , two-tailed Student's $t$ test).

Central expression of mRNA for the progesterone converting enzymes in late pregnancy

Both $5 \alpha$-reductase and $3 \alpha$-HSD are expressed in white matter (Melcangi et al., 1990; Lauber and Lichtensteiger, 1996). There was no difference in mRNA expression for either enzyme in the pyramidal tract [grain area $\left(\mu \mathrm{m}^{2} / \mu \mathrm{m}^{2}\right): 5 \alpha$-reductase mRNA, $66.6 \pm 8.3$ in virgin rats vs $74.2 \pm 14.1$ in day 21 pregnant rats, $p>0.05 ; 3 \alpha$-HSD mRNA, $8.9 \pm 1.2$ in virgin rats vs $8.2 \pm 0.7$ in day 21 pregnant rats, $p>0.05$ two-tailed Student's $t$ test; $n=6$ per group]. There was no difference in $5 \alpha$-reductase mRNA ex- 
PVN

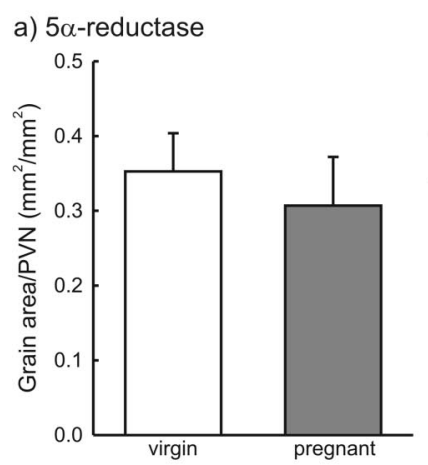

c) $3 \alpha-H S D$

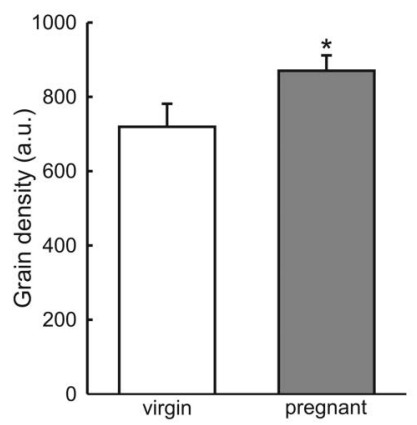

e) $3 \alpha-H S D: P V N$

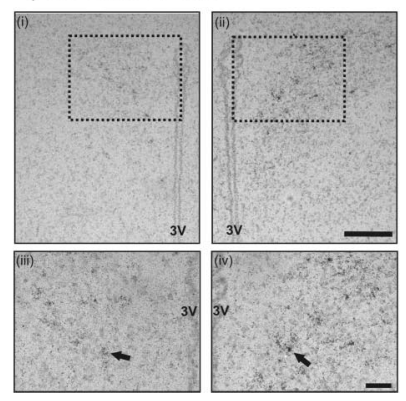

NTS A2

b) $5 \alpha$-reductase

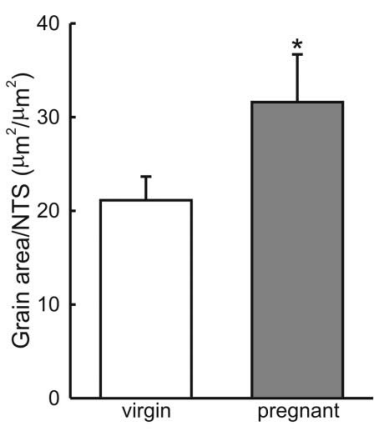

d) $3 \alpha-H S D$

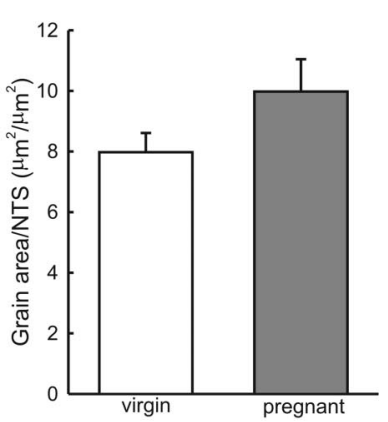

f) $5 \alpha$-reductase: NTS

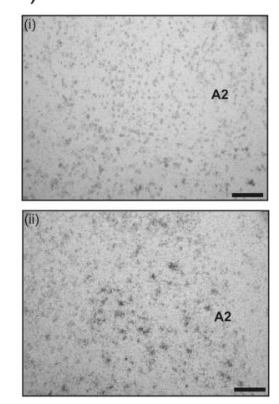

Figure 4. Central expression of mRNA for the progesterone converting enzymes in late pregnancy. Virgin and day 21 pregnant rats were killed by conscious decapitation, and brains were processed by in situ hybridization using ${ }^{35}$ S-labeled riboprobes complementary to rat $5 \alpha$ reductase mRNA and rat $3 \alpha$-HSD mRNA. $\boldsymbol{a}, \boldsymbol{b}$, Quantification of $5 \alpha$-reductase mRNA expression in the PVN $(\boldsymbol{a})$ and $5 \alpha$-reductase mRNA expression in the A2 region of the NTS $(\boldsymbol{b})$. Data are expressed as the grain area per PVN $\left(\mathrm{mm}^{2} / \mathrm{mm}^{2}\right)$ or NTS $\left(\mu \mathrm{m}^{2} / \mu \mathrm{m}^{2}\right)$ profile. ${ }^{*} p<0.05$ versus virgin group. $\boldsymbol{c}, \boldsymbol{d}$, Quantification of $3 \alpha$-HSD mRNA in the PVN (c) and $3 \alpha$-HSD mRNA expression in the A2 region of the NTS ( $\boldsymbol{d}$ ). Data are expressed either as mean grain density/PVN [expressed as arbitrary units (a.u.); the mean grain density per neuron times number of neurons positively expressing $3 \alpha$-HSD mRNA) or as grain area per NTS profile $\left(\mu \mathrm{m}^{2} / \mu \mathrm{m}^{2}\right)$. ] ${ }^{*} p<0.05$ versus virgin group. $n=5-6$ rats per group. All values are group means \pm SEM. $e$, Representative photomicrographs of $3 \alpha-H S D$ mRNA expression in the PVN of virgin (i) and pregnant (ii) rats. Highermagnification views of the areas indicated by the dashed box are shown from virgin (iii) and pregnant (iv) rats. 3V, Third ventricle. Scale bars: top, $200 \mu \mathrm{m}$; bottom, $100 \mu \mathrm{m}$. Filled arrows indicate positive cells. $f$, Representative photomicrographs of $5 \alpha$-reductase mRNA expression in the A2 region of the NTS from virgin (i) and pregnant (ii) rats. Scale bar, $100 \mu \mathrm{m}$.

pression in the PVN between virgin and late pregnant rats (Fig. $4 a$ ), but $5 \alpha$-reductase mRNA levels were significantly greater in the A2 region of the NTS of the late pregnant group compared with the nonpregnant group (Fig. $4 b, f)(p=0.047$, one-tailed Student's $t$ test). There was a modest but significant increase in $3 \alpha$-HSD mRNA expression in the PVN in late pregnant rats compared with virgin rats (Fig. $4 c, e)(p=0.042)$, but a significant difference in the level of $3 \alpha$-HSD mRNA expression in the A2 region of the NTS was not detected between virgin and pregnant rats (Fig. $4 d)(p=0.069)$.

\section{Activity of the progesterone converting enzymes in the brain in late pregnancy}

$5 \alpha$-Reductase activity was significantly greater in the hypothalamus in late pregnant rats compared with virgin rats ( $\left[{ }^{3} \mathrm{H}\right]$ progesterone conversion into DHP was $2.6 \pm 0.5 \%$ in the virgin group, $n=8$ vs $5.6 \pm 0.8 \%$ in the late pregnant group, $n=6 ; p=0.033$, one-tailed Student's $t$ test). $3 \alpha$-HSD activity also tended to be greater in the hypothalamus in pregnant rats, but this was not statistically significant $\left(\left[{ }^{3} \mathrm{H}\right]\right.$ progesterone conversion into AP was $0.3 \pm 0.1 \%$ in the virgin group, $n=8$ vs $0.7 \pm 0.3 \%$ in the late pregnant group, $n=6 ; p=0.07)$. No difference was detected in the activities of either enzyme in the medulla oblongata ( $\left[{ }^{3} \mathrm{H}\right]$ progesterone conversion into DHP was $2.6 \pm 0.7 \%$ in the virgin group vs $3.2 \pm 0.8 \%$ in the late pregnant group, $p>0.05$; $\left[{ }^{3} \mathrm{H}\right]$ progesterone conversion into $\mathrm{AP}$ was $0.3 \pm 0.1 \%$ in the virgin group vs $0.4 \pm 0.1 \%$ in the late pregnant group, $p>0.05$ ).

\section{Effect of blocking allopregnanolone synthesis and endogenous opioid action on HPA axis responses to IL-1 $\beta$ in late pregnant rats}

There was a significant effect of finasteride $\left(F_{(1,20)}=13.9, p<\right.$ 0.001 , mixed ANOVA) and naloxone $\left(F_{(1,20)}=4.4, p=0.048\right)$ treatment on $\mathrm{ACTH}$ responses to IL- $1 \beta$ in the late pregnant groups (Fig. 5a). Neither finasteride nor naloxone altered basal plasma ACTH concentration in virgin or pregnant rats (Fig. $5 a$ ). IL- $1 \beta$ significantly increased plasma ACTH concentration (3.2fold increase) (Fig. 5a,b) in the vehicle-pretreated virgin rats but had no significant effect in the vehicle-pretreated pregnant rats (Fig. $5 a, b$ ). Both finasteride only and naloxone only pretreatment restored an $\mathrm{ACTH}$ response to IL- $1 \beta$ in the late pregnant rats to 71 and $65 \%$ of the response observed in the virgin controls, respectively (Fig. 5a,b). However, combined finasteride and naloxone pretreatment had no additional effect on the ACTH response to IL- $1 \beta$ in late pregnant rats compared with either naloxone or finasteride treatment alone (Fig. $5 a, b)$. In a separate experiment, naloxone $(5 \mathrm{mg} / \mathrm{kg}$, i.v., with no subsequent IL- $1 \beta$ treatment) had no effect on plasma ACTH concentration over a $90 \mathrm{~min}$ period in either virgin or late pregnant rats (Fig. $5 c)(p>0.05$, mixed ANOVA).

Plasma corticosterone concentrations before IL-1 $\beta$ administration were as follows: virgin/oil/saline, $106.6 \pm 11.5 \mathrm{ng} / \mathrm{ml}$; pregnant/oil/saline, $121.4 \pm 8.9 \mathrm{ng} / \mathrm{ml}$; pregnant/oil/naloxone, $129.2 \pm 10.1 \mathrm{ng} / \mathrm{ml}$; pregnant/finasteride/saline, $107.0 \pm 9.7 \mathrm{ng} /$ $\mathrm{ml}$; pregnant/finasteride/naloxone, $117.4 \pm 8.9 \mathrm{ng} / \mathrm{ml}$. There was an overall effect of drug treatment $\left(F_{(4,158)}=4.6, p=0.006\right.$, two-way RM ANOVA) on corticosterone responses to IL- $1 \beta$. IL-1 $\beta$ significantly increased plasma corticosterone concentration in the vehicle-treated virgin but not pregnant rats (Fig. $5 d, e$ ). Pretreatment with finasteride alone, naloxone alone, or combined finasteride and naloxone all restored corticosterone responses to IL- $1 \beta$ in the pregnant groups, with no significant differences between groups or compared with the vehicle-treated virgin rats (Fig. $5 d, e$ ).

There was a significant effect of pregnancy status $\left(F_{(1,31)}=\right.$ $25.9, p<0.001$, two-way ANOVA $)$ and drug treatment $\left(F_{(3,31)}=\right.$ $5.0, p=0.006)$ on CRH mRNA expression. CRH mRNA expression in the pPVN $4 \mathrm{~h}$ after systemic IL- $1 \beta$ was significantly less in vehicle-pretreated pregnant rats than in vehicle-treated virgin rats (Fig. 5f). Pretreatment with finasteride alone, naloxone alone, or combined finasteride and naloxone all resulted after 
a)

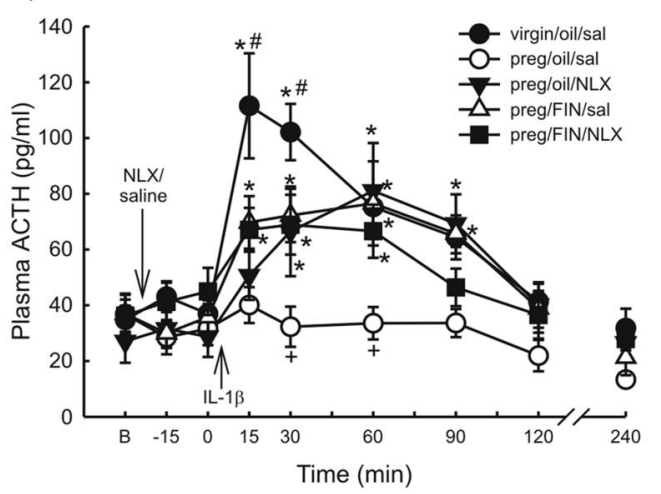

d)

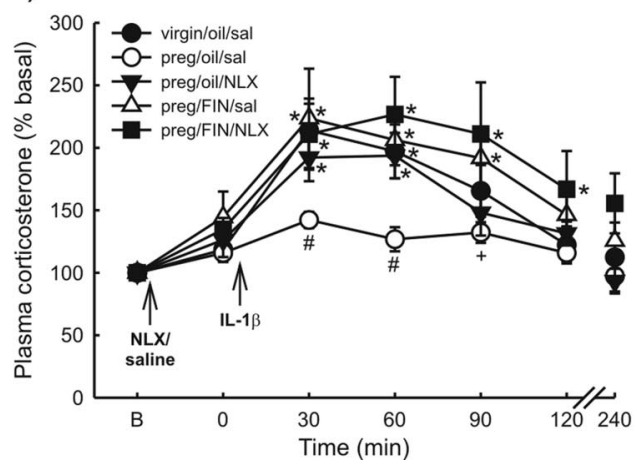

b) 30 min post IL-1 $\beta$

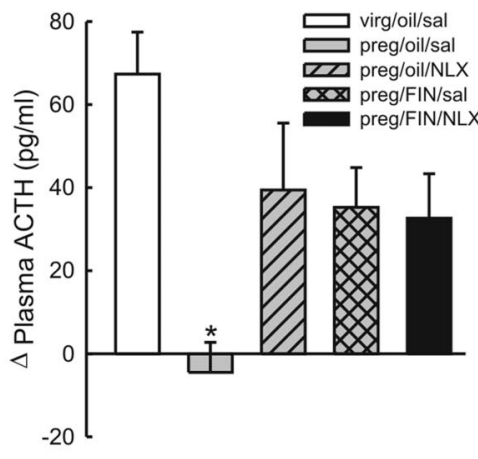

e) $30 \mathrm{~min}$ post IL-1 $\beta$

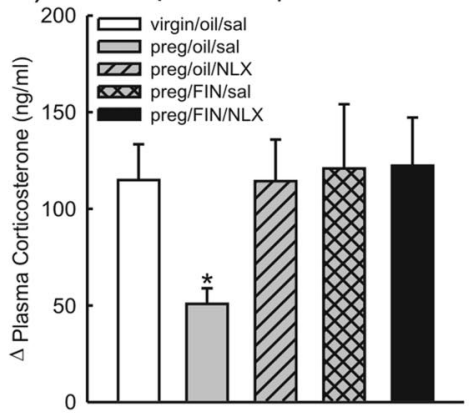

c)

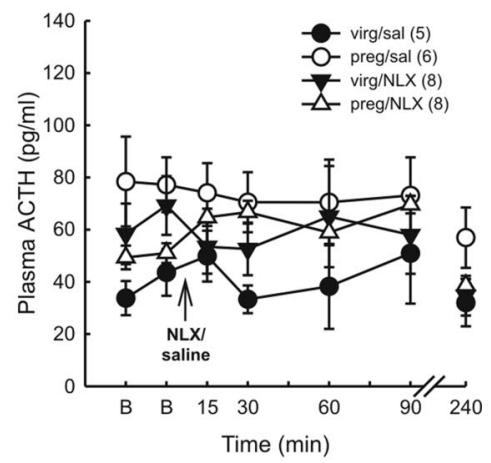

f) $\mathrm{CRH}$ mRNA

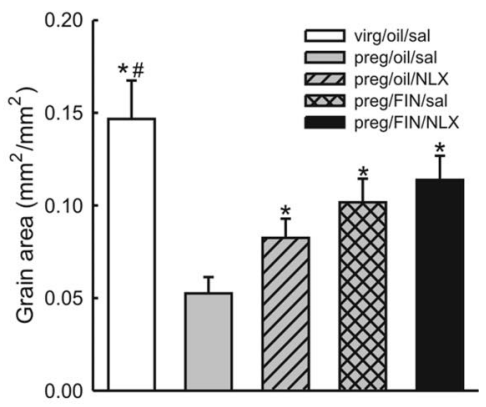

Figure 5. Effect of inhibiting allopregnanolone synthesis and endogenous opioid action on HPA axis responses to IL-1 $\beta$ in late pregnancy. Day 21 pregnant (preg) rats were treated with either finasteride (FIN; $25 \mathrm{mg} / \mathrm{kg}$, s.c.) or vehicle (oil) 20 and $2 \mathrm{~h}$ before IL-1 $\beta$. After a basal (B) blood sample (at $t=-31 \mathrm{~min}$ ), rats were administered naloxone (NLX; $5 \mathrm{mg} / \mathrm{kg}$, i.v.) or vehicle [saline (sal); $0.5 \mathrm{ml} / \mathrm{kg}$, i.v.]. Two additional blood samples were collected at -16 and $-1 \mathrm{~min}$, after which all rats were administered IL- $1 \beta$ ( $500 \mathrm{ng} / \mathrm{kg}$, i.v.) at $t=0 \mathrm{~min}$. Additional blood samples were taken $15,30,60,90$, and $120 \mathrm{~min}$ after treatment. Trunk blood was collected at $t=240 \mathrm{~min}$. A group of virgin rats pretreated with vehicle (oil) and then saline before IL-1 $\beta$ administration was included for comparison. $\boldsymbol{a}, \boldsymbol{b}$, Plasma ACTH concentration $(\boldsymbol{a})$ and increase in ACTH secretion $(\boldsymbol{b})$ from basal levels 30 min after IL-1 $\beta$. $\boldsymbol{c}$, Plasma ACTH concentration in a separate group of virgin and day 21 pregnant (preg) rats before and after treatment only with naloxone ( $\mathrm{NLX} ; 5 \mathrm{mg} / \mathrm{kg}$, i.v.) or saline $(0.5 \mathrm{ml} / \mathrm{kg}$, i.v.) administration. No significant differences within or between groups were detected. $\boldsymbol{d}, \boldsymbol{e}$, Plasma corticosterone concentration ( $\boldsymbol{d})$ and increase in corticosterone secretion $(\boldsymbol{e})$ from basal levels 30 min after IL-1 $\beta$ from the same rats shown in $\boldsymbol{a}$ and $\boldsymbol{b} . n=6-7$ rats per group. $\boldsymbol{a},{ }^{*} p<$ 0.04 versus basal values in the same group; ${ }^{\#} p<0.04,{ }^{+} p<0.007$ versus all other groups at the same time point; $\boldsymbol{b},{ }^{*} p<0.001$ versus all other groups; $\boldsymbol{d},{ }^{*} p<0.009$ versus basal values in the same group; ${ }^{\#} p<0.008$ versus all other groups at the same time point; ${ }^{+} p<0.02$ versus preg/FIN/NLX group. $e^{*} p<0.05$ versus all other groups. Rats were killed $4 \mathrm{~h}$ after IL-1 $\beta$ administration, and brains were processed by in situ hybridization. $f$, Quantification of CRH mRNA expression in the pPVN. $n=6-8$ rats per group. $f$, $p<0.05$, $p<<0.001$ versus preg/oil/saline group. All values are group means \pm SEM.

IL- $1 \beta$ in similar levels of CRH mRNA expression in the pPVN of late pregnant rats that were significantly greater than in the vehicle-treated pregnant group (Fig. $5 f$ ). Naloxone alone (i.e., no subsequent IL- $1 \beta$ treatment) had no effect after $4 \mathrm{~h}$ on basal CRH mRNA expression in the pPVN (same rats as in Fig. $5 c$ ); the mean \pm SEM number of CRH mRNA-expressing cells in the pPVN was as follows: virgin/saline, $228.1 \pm 13.4(n=10)$; virgin/ naloxone, $221.2 \pm 12.2(n=5)$; pregnant/saline, $176.5 \pm 16.4$ $(n=10)$; pregnant/naloxone, $176.6 \pm 18.3(n=6)$. There was no significant effect of naloxone on CRH mRNA in the virgin or the pregnant rats $(p>0.05$, two-way ANOVA), but there was an effect of pregnancy $\left(F_{(1,27)}=8.3, p=0.008\right)$. As detailed above, finasteride alone had no effect on CRH mRNA expression in the pPVN of late pregnant rats.

\section{Effect of allopregnanolone treatment on induction of inhibitory} opioid tone over HPA axis responses to IL-1 $\beta$ in virgin rats There was a significant effect of the allopregnanolone treatment $\left(F_{(1,109)}=6.2, p=0.023\right.$, two-way RM ANOVA) within the saline-treated rats on plasma ACTH concentrations (Fig. 6a). Moreover, within the allopregnanolone-treated rats, there was a significant effect of naloxone treatment $\left(F_{(1,105)}=4.0, p=\right.$ 0.048). There was no difference in basal ACTH secretion among vehicle- and allopregnanolone-pretreated virgin rats with or without naloxone treatment (Fig. 6a). In the vehicle (oil)pretreated groups, IL- $1 \beta$ significantly increased plasma ACTH concentration, with no effect of previous naloxone treatment (Fig. 6a,b). As before (Fig. 2), IL-1 $\beta$ induced a significant increase in ACTH secretion in the AP/saline-treated group (2.2-fold increase), but the amplitude of the response was attenuated compared with the virgin control group (3.8-fold increase) (Fig. 6b). Moreover, the suppressive effect of AP on the ACTH response to IL- $1 \beta$ was completely reversed in the presence of naloxone (Fig. $6 a, b)$. Similarly, CRH mRNA expression in the pPVN $4 \mathrm{~h}$ after IL- $1 \beta$ administration was less in the virgin rats treated with AP alone compared with the controls (Fig. $6 c)\left(F_{(1,36)}=5.5, p=\right.$ 0.025 , two-way ANOVA). This effect of AP was reversed in rats coadministered naloxone (Fig. 6c).

\section{Effect of allopregnanolone treatment on central opioid gene} expression in virgin rats

Mimicking pregnancy in virgin rats with allopregnanolone treatment significantly increased pENK-A mRNA expression in the A2 region of the NTS (Fig. 7a,b) $(p<0.001$, one-tailed Student's $t$ test). This was a consequence of both an increase in the number of neurons expressing pENK-A mRNA and an increase in the 
a)

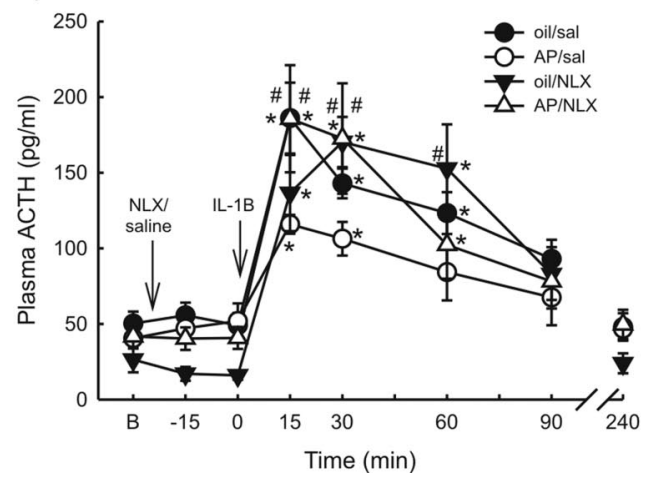

b) 15 min post IL-1 $\beta$

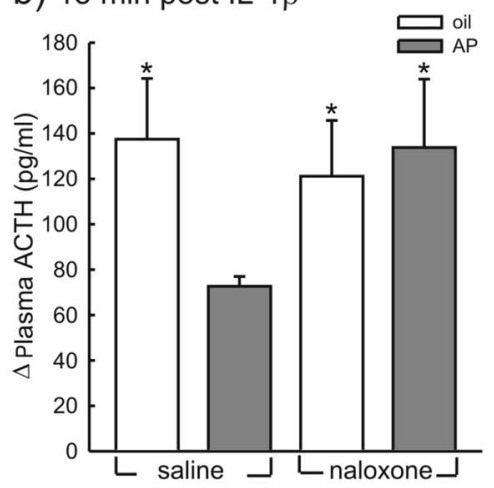

c)

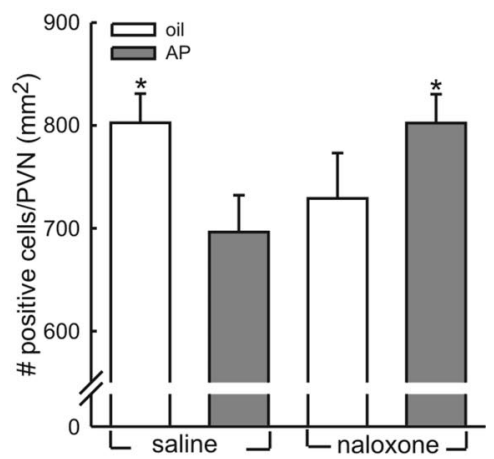

Figure 6. Effect of allopregnanolone treatment on induction of inhibitory opioid tone over HPA axis responses to IL- $1 \beta$ in virgin rats. Virgin rats were treated with allopregnanolone ( 3 and 1 $\mathrm{mg} / \mathrm{kg}$, s.c., 20 and $2 \mathrm{~h}$ before IL-1 $\beta$, respectively) or vehicle (oil). After a basal (B) blood sample (at $t=-31 \mathrm{~min}$ ), rats were administered naloxone (NLX; $5 \mathrm{mg} / \mathrm{kg}$, i.v.) or vehicle [saline (sal); 0.5 $\mathrm{ml} / \mathrm{kg}$, i.v.]. Two additional blood samples were collected at $-16 \mathrm{and}-1 \mathrm{~min}$, after which all rats were administered IL-1 $\beta$ ( $500 \mathrm{ng} / \mathrm{kg}$, i.v.) at $t=0 \mathrm{~min}$. Additional blood samples were taken 15 , $30,60,90$, and 120 min after treatment. Trunk blood was collected at $t=240$ min. $\boldsymbol{a}, \boldsymbol{b}$, Plasma ACTH concentration $(\boldsymbol{a})$ and increase in ACTH secretion $(\boldsymbol{b})$ from post-naloxone levels 15 min after $\mathrm{IL}-1 \beta . n=8-10$ rats per group. $\boldsymbol{a},{ }^{*} p<0.05$ versus basal values in the same group; ${ }^{\#} p<0.04$ versus AP/sal group; $\boldsymbol{b},{ }^{*} p<0.05$ versus AP/sal group. Rats were killed $4 \mathrm{~h}$ after IL-1 $\beta$ administration, and brains were processed by in situ hybridization. c, CRH mRNA expression in the pPVN. Quantification by in situ hybridization $4 \mathrm{~h}$ after intravenous IL-1 $\beta$, expressed as number of neurons expressing CRH mRNA per unit area pPVN. $n=8-13$ rats per group. ${ }^{*} p<0.04$ versus AP/saline group. All values are group means \pm SEM.

a)

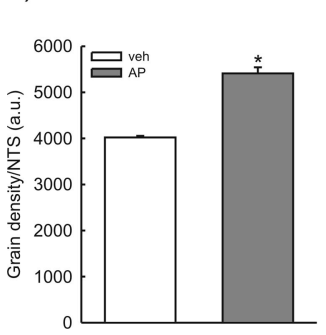

b)

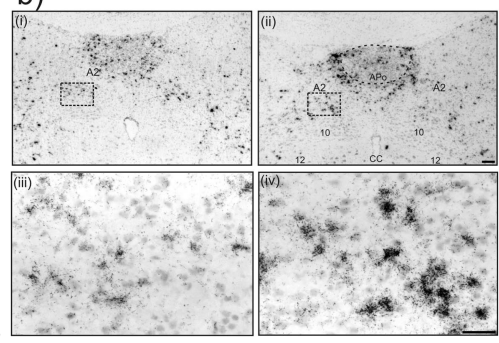

Figure 7. Effect of allopregnanolone and finasteride on opioid mRNA expression in NTS. $a, p E N K-A$ mRNA expression in the A2 region of the NTS in virgin rats treated with $\mathrm{AP}$ ( 3 and $1 \mathrm{mg} / \mathrm{kg}$, s.c.) or vehicle (veh) at $t=-20$ and $-2 \mathrm{~h}$. Brains were collected at $t=0 \mathrm{~h}$. ${ }^{*} p<0.001$ versus vehicle group. Grain density per NTS [in arbitrary units (a.u.)] is the number of positive cells per NTS section times grain density per cell. $\boldsymbol{b}$, Representative photomicrographs of pENK-A mRNA in the A2 region of the NTS from vehicle-treated virgin (i) and AP-treated virgin (ii) rats. AP0, Area postrema; CC, central canal; 10, dorsal motor nucleus of vagus; 12, hypoglossal nucleus. Scale bars: top, $100 \mu \mathrm{m}$; bottom, $25 \mu \mathrm{m}$. Vehicle-treated virgin (iii) and AP-treated virgin (iv) rats; higher-magnification views are indicated by the dashed box. c, pENK-A mRNA expression in the A2 region of the NTS in day 21 pregnant rats treated with finasteride (FIN; $25 \mathrm{mg} / \mathrm{kg}$, s.c.) or vehicle (veh) at $t=-20$ and $-2 \mathrm{~h}$. Brainswere collected at $t=0 \mathrm{~h}$. ${ }^{*} p<$ 0.01 versus veh group. Grain density was calculated as above. $n=5-7$ rats per group. All values are group means \pm SEM.

levels of expression per neuron (Table 2). Allopregnanolone treatment had no significant effect on pENK-A mRNA expression in the pPVN, magnocellular division of the PVN or the arcuate nucleus (Table 2). There were also no significant differences in POMC mRNA expression in the arcuate nucleus or $\mu$-opioid receptor mRNA expression in the NTS (Table 2). In late pregnant rats, $20 \mathrm{~h}$ finasteride treatment resulted in a significant reduction in pENK-A mRNA expression in the $\mathrm{A} 2$ region of the NTS (Fig. $7 c)(p=0.003)$.

\section{Discussion}

Our results demonstrate that allopregnanolone restrains HPA axis responses to immune challenge in late pregnancy and implicate mediation of allopregnanolone actions by activation of endogenous opioid expression in the NTS.

\section{Role of allopregnanolone}

HPA responses to IL- $1 \beta$ were suppressed in late pregnancy as found previously (Brunton et al., 2005). Blocking allopregnanolone production with finasteride [previously shown to decrease cortical allopregnanolone content by $90 \%$ (Concas et al., c)

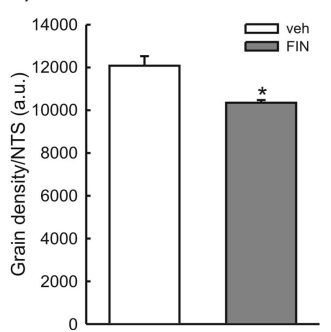

temic IL- $1 \beta$ challenge.

1998)] restored HPA axis responses to IL- $1 \beta$ in pregnant rats, reflected by increased CRH mRNA expression in the pPVN, and ACTH and corticosterone secretion, whereas concurrent allopregnanolone treatment prevented these finasteride effects. Furthermore, we mimicked reduced pregnancy-type HPA axis responses to IL- $1 \beta$ in nonpregnant rats with short-term $(2-20 \mathrm{~h})$ allopregnanolone treatment. Central effects were shown because, in pregnant rats finasteride enhanced and in virgin rats allopregnanolone treatment reduced the increase in pPVN CRH mRNA expression after systemic IL-1 $\beta$. These treatments did not affect basal pPVN CRH mRNA expression or basal plasma ACTH or corticosterone concentrations. Hence, the neurosteroid manipulations specifically altered HPA responses to the sys-

Systemic IL- $1 \beta$ activates pPVN CRH neurons via brainstem noradrenergic A2 neurons (Rivest et al., 2000) but is ineffective in late pregnancy (Brunton et al., 2005). It is unclear where in the brain allopregnanolone acts to exert its suppressive effects on HPA responses to IL- $1 \beta$. Allopregnanolone may prevent stimulation of CRH neurons in the PVN by noradrenaline (Patchev et al., 1994) or it may inhibit CRH neurons by modulating GABA inputs to the PVN by its actions on $\mathrm{GABA}_{\mathrm{A}}$ receptors. For example, GABA neurons in the peri-PVN area mediate glucocorticoid negative feedback (Di et al., 2009), whereas GABA neurons in the bed nucleus of stria terminalis (Cullinan et al., 2008) can modulate HPA responses to IL-1 $\beta$ (Crane et al., 2003).

The NTS contains intrinsic GABA neurons (Fong et al., 2005; Bailey et al., 2008), GABA-containing terminals, and $\mathrm{GABA}_{\mathrm{A}}$ receptor subunits (Terai et al., 1998; Saha et al., 2001), and GABA release in the NTS is increased by depolarization (Sved and Curtis, 1993). Effects of GABA on NTS neurons identified as projecting to the PVN are not reported, nonetheless GABA inhibits the electrical activity of A2 neurons (Moore and Guyenet, 1983) and 
GABA injected into the NTS inhibits noradrenaline release in the subfornical organ (Tanaka et al., 2002). Moreover, GABA neurons can express $5 \alpha$-reductase and $3 \alpha$-HSD (Agís-Balboa et al., 2006). Hence, in late pregnancy, allopregnanolone might enhance GABA action at the PVN, or on its inputs, including in the NTS, to attenuate HPA axis stress responses.

\section{Allopregnanolone-synthesizing enzymes}

Neither of the allopregnanolone precursors progesterone nor DHP reduced HPA responses to IL- $1 \beta$ in virgin rats, indicating ineffective conversion to allopregnanolone. In contrast, in the NTS in late pregnancy, $5 \alpha$-reductase (the rate-limiting enzyme) mRNA expression was increased, and $3 \alpha$-HSD mRNA levels tended to increase $(p=0.07)$. Metabolism of progesterone by $5 \alpha$-reductase and $3 \alpha$-HSD in the medulla has been described previously (Hanukoglu et al., 1977), but we found no change in pregnancy. Levels of $3 \alpha$-HSD mRNA (but not $5 \alpha$-reductase mRNA) were increased in the PVN in late pregnancy. Furthermore, $5 \alpha$-reductase activity was increased (whereas $3 \alpha$-HSD activity tended to increase) in the hypothalamus in late pregnancy. Together, these data indicate increased allopregnanolone generation in late pregnancy in brain regions involved in stressor processing.

Discrepancies between enzyme mRNA levels and activity changes in pregnancy likely reflect the highly localized mRNA measurements (PVN and NTS), whereas activity measurements were made in whole hypothalamus and medulla. Increased allopregnanolone production by the NTS would be obscured by the predominance of elements such as the pyramidal tracts with abundant $5 \alpha$-reductase activity (Melcangi et al., 1988), in which we found no changes in mRNA expression in pregnancy. Nonetheless, increased $5 \alpha$-reductase mRNA (and $3 \alpha$-HSD mRNA) expression in the NTS in late pregnancy is expected to lead to increased allopregnanolone generation for local action on A2 neurons, presumptively via $\mathrm{GABA}_{\mathrm{A}}$ receptors. It is worth noting that allopregnanolone can also act via progesterone receptors after intracellular conversion to $5 \alpha$-DHP (Rupprecht, 2003), but because few A2 cells express progesterone receptor in pregnancy (Francis et al., 2002), it is unlikely allopregnanolone exerts its actions in the NTS through these receptors.

Presumably, increased activity of the central synthesizing enzymes contributes to the increased brain content of allopregnanolone in pregnancy (Concas et al., 1998), although peripheral production is also likely to be a factor. $5 \alpha$-Reductase and $3 \alpha$-HSD are highly expressed in liver (Pirog and Collins, 1994; Torres and Ortega, 2004), but changes in rat pregnancy are not known. In the mouse, $5 \alpha$-reductase mRNA in the liver is increased during midpregnancy, whereas the placenta expresses little after day 10 (Mahendroo et al., 1997).

$5 \alpha$-Reductase and $3 \alpha$-HSD also metabolize 11-deoxycorticosterone (DOC), from the adrenal cortex, to $3 \alpha, 5 \alpha$-tetrahydrodeoxycorticosterone (TH-DOC), a neurosteroid acting like allopregnanolone (Womack et al., 2006). DOC secretion is increased by acute stress (Reddy and Rogawski, 2002a), but finasteride actions via decreased TH-DOC formation in the current study are unlikely because corticosterone levels in pregnant rats were no greater than in virgins.

\section{Regulation of $5 \alpha$-reductase and $3 \alpha$-HSD}

The factor(s) responsible for regulating central expression of $5 \alpha$ reductase and $3 \alpha$-HSD are unclear. Putative candidates are sex steroids, but to date, neither estrogen nor progesterone is known to regulate $5 \alpha$-reductase type 1 expression in the brain. $3 \alpha$-HSD activity in the hypothalamus can be regulated by ovarian hormones (Bertics et al., 1987), and estrogen, but not progesterone, can increase hippocampal $3 \alpha$-HSD mRNA expression (Mitev et al., 2003).

$5 \alpha$-Reductase gene expression in the female forebrain is stimulated by dihydrotestosterone (Torres and Ortega, 2006); however, whether other $5 \alpha$-reduced steroids, such as allopregnanolone can regulate expression, is not known. In pregnancy, increased levels of prolactin may play a role in upregulating $5 \alpha$ reductase gene expression in the forebrain (Sánchez et al., 2008).

\section{Endogenous opioids}

Reduced HPA responses to IL- $1 \beta$ in late pregnancy involve opioid inhibition of noradrenaline release in the PVN, potentially by met-enkephalin coproduced in NTS neurons projecting to the PVN (Beaulieu et al., 1996), because NTS pENK-A and MOR mRNA expression increase in late pregnancy (Brunton et al., 2005). Here, combined finasteride and naloxone treatment had no greater effect in restoring HPA axis responses to IL- $1 \beta$ in late pregnancy than either drug alone. Finasteride and naloxone, alone or combined, fully restored the corticosterone profile but not the ACTH levels to the virgin values. Enhanced sensitivity to $\mathrm{ACTH}$ as a result of high estrogen levels in pregnancy can explain such lack of fidelity between the ACTH and corticosterone responses (Figueiredo et al., 2007). The capacity of the anterior pituitary to generate an ACTH response to stress is not reduced in late pregnancy (Ma et al., 2005), indicating that some central HPA elements remain hypoactive even after finasteride and naloxone treatment. Nonetheless, lack of additive effects of finasteride and naloxone indicated interlinked allopregnanolone and opioid mechanisms. Indeed, allopregnanolone induced opioid inhibition over HPA axis responses to IL- $1 \beta$ in virgin rats. Moreover, allopregnanolone treatment for $20 \mathrm{~h}$ upregulated pENK-A mRNA expression in the NTS of virgin rats by $35 \%$, consistent with the 31\% increase reported in late pregnancy (Brunton et al., 2005). Furthermore, finasteride reduced pENK-A mRNA expression in the NTS of late pregnant rats, likely explaining how finasteride restores HPA axis responses to IL- $1 \beta$.

Regulation of opioid expression in the NTS by allopregnanolone might involve interaction with $\mathrm{GABA}_{\mathrm{A}}$ receptors, but such action inhibits PVN oxytocin mRNA expression (Blyth et al., 2000) and direct $\mathrm{GABA}_{\mathrm{A}}$ receptor activation inhibits pPVN pENK-A, CRH, and vasopressin mRNA expression (Borsook et al., 1999; Bali and Kovács, 2003).

Changes in pENK-A mRNA expression in the NTS after treatment with allopregnanolone in virgins or finasteride in pregnant rats were seen within $20 \mathrm{~h}$. Rapid increases in pENK-A mRNA expression have been described after acute stress in the NTS (Boone and McMillen, 1994) and in the pPVN (García-García et al., 1998), which are dependent on increased corticosterone, at least in the case of the PVN (García-García et al., 1998). Here, the changes in pENK-A mRNA in the NTS were not related to basal plasma corticosterone levels, because these were unaltered by pregnancy or by allopregnanolone or finasteride treatment.

Allopregnanolone treatment did not alter MOR mRNA expression in the NTS, which is increased by day 10 of pregnancy (Brunton et al., 2005). Upregulation of MOR may rely on increased levels of circulating estrogen in pregnancy (Zhu and Pfaff, 1995; Eckersell et al., 1998; Priest and Roberts, 2000).

It remains to be shown whether allopregnanolone induction of pENK-A mRNA in the NTS leads to preterminal inhibition of noradrenaline release in the pPVN after systemic IL-1 $\beta$ as in pregnancy (Brunton et al., 2005). 
We conclude that the emergence and maintenance of endogenous opioid inhibition of HPA axis responses to stress in late pregnancy depends on central actions of increased levels of allopregnanolone. This novel allopregnanolone-induced opioid mechanism may regulate other neuroendocrine mechanisms in pregnancy (Brunton and Russell, 2008).

\section{References}

Agís-Balboa RC, Pinna G, Zhubi A, Maloku E, Veldic M, Costa E, Guidotti A (2006) Characterization of brain neurons that express enzymes mediating neurosteroid biosynthesis. Proc Natl Acad Sci U S A 103:14602-14607.

Bailey TW, Appleyard SM, Jin YH, Andresen MC (2008) Organization and properties of GABAergic neurons in solitary tract nucleus (NTS). J Neurophysiol 99:1712-1722.

Bali B, Kovács KJ (2003) GABAergic control of neuropeptide gene expression in parvocellular neurons of the hypothalamic paraventricular nucleus. Eur J Neurosci 18:1518-1526.

Beaulieu J, Champagne D, Drolet G (1996) Enkephalin innervation of the paraventricular nucleus of the hypothalamus: distribution of fibers and origins of input. J Chem Neuroanat 10:79-92.

Bertics SJ, Bertics PJ, Clarke JL, Karavolas HJ (1987) Distribution and ovarian control of progestin-metabolizing enzymes in various rat hypothalamic regions. J Steroid Biochem 26:321-328.

Blyth BJ, Hauger RL, Purdy RH, Amico JA (2000) The neurosteroid allopregnanolone modulates oxytocin expression in the hypothalamic paraventricular nucleus. Am J Physiol Regul Integr Comp Physiol 278:R684-R691.

Boone JB Jr, McMillen D (1994) Differential effects of prolonged restraint stress on proenkephalin gene expression in the brainstem. Brain Res Mol Brain Res 27:290-298.

Borsook D, Smirnova O, Behar O, Lewis S, Kobierski LA (1999) PhosphoCREB and CREM/ICER: positive and negative regulation of proenkephalin gene expression in the paraventricular nucleus of the hypothalamus. J Mol Neurosci 12:35-51.

Brunton PJ, Russell JA (2008) The expectant brain: adapting for motherhood. Nat Rev Neurosci 9:11-25.

Brunton PJ, Meddle SL, Ma S, Ochedalski T, Douglas AJ, Russell JA (2005) Endogenous opioids and attenuated hypothalamic-pituitary-adrenal axis responses to immune challenge in pregnant rats. J Neurosci 25:5117-5126.

Brunton PJ, Russell JA, Douglas AJ (2008) Adaptive responses of the maternal hypothalamic-pituitary-adrenal axis during pregnancy and lactation. J Neuroendocrinol 20:764-776.

Buller K, Xu Y, Dayas C, Day T (2001) Dorsal and ventral medullary catecholamine cell groups contribute differentially to systemic interleukin1beta-induced HPA axis responses. Neuroendocrinology 73:129-138.

Choi DC, Furay AR, Evanson NK, Ostrander MM, Ulrich-Lai YM, Herman JP (2007) Bed nucleus of the stria terminalis subregions differentially regulate hypothalamic-pituitary-adrenal axis activity: implications for the integration of limbic inputs. J Neurosci 27:2025-2034.

Compagnone NA, Mellon SH (2000) Neurosteroids: biosynthesis and function of these novel neuromodulators. Front Neuroendocrinol 21:1-56.

Concas A, Mostallino MC, Porcu P, Follesa P, Barbaccia ML, Trabucchi M, Purdy RH, Grisenti P, Biggio G (1998) Role of brain allopregnanolone in the plasticity of gamma-aminobutyric acid type A receptor in rat brain during pregnancy and after delivery. Proc Natl Acad Sci U S A 95:13284-13289.

Crane JW, Buller KM, Day TA (2003) Evidence that the bed nucleus of the stria terminalis contributes to the modulation of hypophysiotropic corticotropin-releasing factor cell responses to systemic interleukin1beta. J Comp Neurol 467:232-242.

Cullinan WE, Ziegler DR, Herman JP (2008) Functional role of local GABAergic influences on the HPA axis. Brain Struct Funct 213:63-72.

Di S, Maxson MM, Franco A, Tasker JG (2009) Glucocorticoids regulate glutamate and GABA synapse-specific retrograde transmission via divergent nongenomic signaling pathways. J Neurosci 29:393-401.

Douglas AJ, Johnstone H, Brunton P, Russell JA (2000) Sex-steroid induction of endogenous opioid inhibition on oxytocin secretory responses to stress. J Neuroendocrinol 12:343-350.

Eckersell CB, Popper P, Micevych PE (1998) Estrogen-induced alteration of mu-opioid receptor immunoreactivity in the medial preoptic nucleus and medial amygdala. J Neurosci 18:3967-3976.
Ericsson A, Kovács KJ, Sawchenko PE (1994) A functional anatomical analysis of central pathways subserving the effects of interleukin-1 on stressrelated neuroendocrine neurons. J Neurosci 14:897-913.

Figueiredo HF, Ulrich-Lai YM, Choi DC, Herman JP (2007) Estrogen potentiates adrenocortical responses to stress in female rats. Am J Physiol Endocrinol Metab 292:E1173-E1182.

Fong AY, Stornetta RL, Foley CM, Potts JT (2005) Immunohistochemical localization of GAD67-expressing neurons and processes in the rat brainstem: subregional distribution in the nucleus tractus solitarius. J Comp Neurol 493:274-290.

Francis K, Meddle SL, Bishop VR, Russell JA (2002) Progesterone receptor expression in the pregnant and parturient rat hypothalamus and brainstem. Brain Res 927:18-26.

García-García L, Harbuz MS, Manzanares J, Lightman SL, Fuentes JA (1998) RU-486 blocks stress-induced enhancement of proenkephalin gene expression in the paraventricular nucleus of rat hypothalamus. Brain Res 786:215-218.

Hanukoglu I, Karavolas HJ, Goy RW (1977) Progesterone metabolism in the pineal, brain stem, thalamus and corpus callosum of the female rat. Brain Res 125:313-324.

Harbuz MS, Lightman SL (1989) Responses of hypothalamic and pituitary mRNA to physical and psychological stress in the rat. J Endocrinol 122:705-711.

Herd MB, Belelli D, Lambert JJ (2007) Neurosteroid modulation of synaptic and extrasynaptic GABA(A) receptors. Pharmacol Ther 116:20-34.

Lauber ME, Lichtensteiger W (1996) Ontogeny of 5 alpha-reductase (type 1) messenger ribonucleic acid expression in rat brain: early presence in germinal zones. Endocrinology 137:2718-2730.

Ma S, Shipston MJ, Morilak D, Russell JA (2005) Reduced hypothalamic vasopressin secretion underlies attenuated adrenocorticotropin stress responses in pregnant rats. Endocrinology 146:1626-1637.

Mahendroo MS, Cala KM, Landrum DP, Russell DW (1997) Fetal death in mice lacking 5alpha-reductase type 1 caused by estrogen excess. Mol Endocrinol 11:917-927.

Melcangi RC, Celotti F, Ballabio M, Poletti A, Castano P, Martini L (1988) Testosterone 5 alpha-reductase activity in the rat brain is highly concentrated in white matter structures and in purified myelin sheaths of axons. J Steroid Biochem 31:173-179.

Melcangi RC, Celotti F, Ballabio M, Poletti A, Martini L (1990) Testosterone metabolism in peripheral nerves: presence of the 5 alpha-reductase- 3 alpha-hydroxysteroid-dehydrogenase enzymatic system in the sciatic nerve of adult and aged rats. J Steroid Biochem 35:145-148.

Mitev YA, Darwish M, Wolf SS, Holsboer F, Almeida OF, Patchev VK (2003) Gender differences in the regulation of 3 alpha-hydroxysteroid dehydrogenase in rat brain and sensitivity to neurosteroid-mediated stress protection. Neuroscience 120:541-549.

Moore SD, Guyenet PG (1983) Alpha-receptor mediated inhibition of A2 noradrenergic neurons. Brain Res 276:188-191.

Patchev VK, Shoaib M, Holsboer F, Almeida OF (1994) The neurosteroid tetrahydroprogesterone counteracts corticotropin-releasing hormoneinduced anxiety and alters the release and gene expression of corticotropin-releasing hormone in the rat hypothalamus. Neuroscience 62:265-271.

Paxinos G, Watson C (1998) The rat brain in stereotaxic coordinates, Ed 4. San Diego: Academic.

Pirog EC, Collins DC (1994) 3 Alpha-hydroxysteroid dehydrogenase activity in rat liver and skin. Steroids 59:259-264.

Priest CA, Roberts JL (2000) Estrogen and tamoxifen differentially regulate beta-endorphin and cFos expression and neuronal colocalization in the arcuate nucleus of the rat. Neuroendocrinology 72:293-305.

Purdy RH, Morrow AL, Moore PH Jr, Paul SM (1991) Stress-induced elevations of gamma-aminobutyric acid type A receptor-active steroids in the rat brain. Proc Natl Acad Sci U S A 88:4553-4557.

Reddy DS, Rogawski MA (2002) Stress-induced deoxycorticosteronederived neurosteroids modulate $\mathrm{GABA}_{\mathrm{A}}$ receptor function and seizure susceptibility. J Neurosci 22:3795-3805.

Rivest S, Lacroix S, Vallières L, Nadeau S, Zhang J, Laflamme N (2000) How the blood talks to the brain parenchyma and the paraventricular nucleus of the hypothalamus during systemic inflammatory and infectious stimuli. Proc Soc Exp Biol Med 223:22-38.

Rivier C, Vale W, Brown M (1989) In the rat, interleukin-1alpha and -beta 
stimulate adrenocorticotropin and catecholamine release. Endocrinology 125:3096-3102.

Rupprecht R (2003) Neuroactive steroids: mechanisms of action and neuropsychopharmacological properties. Psychoneuroendocrinology 28:139-168.

Saha S, Sieghart W, Fritschy JM, McWilliam PN, Batten TF (2001) Gammaaminobutyric acid receptor $(\mathrm{GABA}(\mathrm{A}))$ subunits in rat nucleus tractus solitarii (NTS) revealed by polymerase chain reaction (PCR) and immunohistochemistry. Mol Cell Neurosci 17:241-257.

Sánchez P, Torres JM, Gavete P, Ortega E (2008a) Effects of swim stress on mRNA and protein levels of steroid 5alpha-reductase isozymes in prefrontal cortex of adult male rats. Neurochem Int 52:426-431.

Sánchez P, Torres JM, Vílchez P, Del Moral RG, Ortega E (2008b) Effects of sulpiride on prolactin and mRNA levels of steroid 5alpha-reductase isozymes in adult rat brain. Neurochem Res 33:820-825.

Sved AF, Curtis JT (1993) Amino acid neurotransmitters in nucleus tractus solitarius: an in vivo microdialysis study. J Neurochem 61:2089-2098.

Tanaka J, Mashiko N, Kawakami A, Ushigome A, Nomura M (2002) GABAergic systems in the nucleus tractus solitarius regulate noradrenaline release in the subfornical organ area in the rat. Auton Neurosci 100:58-65.
Terai K, Tooyama I, Kimura H (1998) Immunohistochemical localization of GABAA receptors in comparison with GABA-immunoreactive structures in the nucleus tractus solitarii of the rat. Neuroscience 82:843-852.

Torres JM, Ortega E (2004) Precise quantitation of steroid 5alpha lambda pi eta alpha-reductase type 1 mRNA levels by RT-PCR in female rat liver. Endocr Res 30:149-157.

Torres JM, Ortega E (2006) Steroid 5alpha-reductase isozymes in the adult female rat brain: central role of dihydrotestosterone. J Mol Endocrinol 36:239-245.

Womack MD, Pyner S, Barrett-Jolley R (2006) Inhibition by alphatetrahydrodeoxycorticosterone (THDOC) of pre-sympathetic parvocellular neurones in the paraventricular nucleus of rat hypothalamus. $\mathrm{Br} \mathrm{J}$ Pharmacol 149:600-607.

Zhang J, Rivest S (1999) Distribution, regulation and colocalization of the genes encoding the EP2- and EP4-PGE2 receptors in the rat brain and neuronal responses to systemic inflammation. Eur J Neurosci 11:2651-2668.

Zhu YS, Pfaff DW (1995) DNA binding of hypothalamic nuclear proteins on estrogen response element and preproenkephalin promoter: modification by estrogen. Neuroendocrinology 62:454-466. 